\title{
Imperial Legacies and Revolutionary Legends: The Sibe Cavalry Company, the Eastern Turkestan Republic, and Historical Memories in Xinjiang
}

\author{
MAX OIDTMANN \\ Georgetown University \\ Volume 12, 2014
}

This essay examines the process of writing and memorializing the past in the post-Mao era in Xinjiang. In particular, this essay concerns the Sibe community and their recollections of the turbulent decades between 1930 and 1949 and their participation in the Eastern Turkestan Republic. Writing in Chinese, Manchu, and Uyghur, Sibe authors have recorded a narrative of the revolutionary period that is significantly different from the "official" narrative of the PRC. They have appropriated the vocabulary of revolution, translated it into Manchu, and used it to talk about their own revolutionary activities in 1944, asserting both their own agency and their ambivalence about their role as an official "minority nationality" in "New China." Moreover, Sibe participation in the ETR reveals the degree to which their martial legacy as Qing bannerpeople continued to complicate self-understandings and political activities well into the $1940 \mathrm{~s}$.

帝国遗產与共和传说：锡伯骑兵连、东突厥斯坦共和国, 以及在新疆的历史 记忆

欧麦高 Max Oidtmann

乔治城大学卡塔尔分校

本文检视了后毛泽东时期在新疆当地对过去进行书写与纪念的过程，并侧重 於锡伯族社群及其对1930至1949年间之动盪与其加入东突厥斯坦共和国的回 忆。锡伯族作家们以汉文、满文与维文记录了一种与中华人民共和国「官 方」论述大相逕庭的革命时代叙事。他们挪用了革命的语汇，并以其来述说 
自身於1944年的革命活动, 而且强调了关于他们在「新中国」作為官方「少 数民族」自身的作用与矛盾。此外，锡伯族加入东突厥斯坦共和国一事也显 示了他们作為清代旗人所拥有的武功遗產，直到1940年代持续将其自我理解 与政治活动复杂化的程度。

帝國遺產與革命傳說：錫伯騎兵連、東突厥斯坦共和國，以及在新疆的歷史 記憶

歐麥高 Max Oidtmann

喬治城大學卡達分校

本文檢視了後毛澤東時期在新疆當地對過去進行書寫與紀念的過程, 並側重 於錫伯族社群及其對1930至1949年間之動盪與其加入東突厥斯坦共和國的回 憶。錫伯族作家們以漢文、滿文與維文記錄了一種與中華人民共和國「官 方」論述大相逕庭的革命時代敘事。他們挪用了革命的語彙，並以其來述說 自身於1944年的革命活動，而且強調了關於他們在「新中國」作為官方「少 數民族」自身的作用與矛盾。此外，錫伯族加入東突厥斯坦共和國一事也顯 示了他們作為清代旗人所擁有的武功遺產，直到1940年代持續將其自我理解 與政治活動複雜化的程度。

\section{Introduction}

The People's Republic of China currently celebrates September 25, 1949, as the date of the "peaceful liberation of Xinjiang." "Yet for contemporary Sibe authors who witnessed "liberation" - or sulambusün in their own language — the revolutionary period actually began a full five years earlier, in the fall of 1944. That fall, ethnic Sibe partisans were among the first contingents of guerrilla fighters who began to challenge the rule of the Chinese Nationalist Party (GMD) in the Ili Valley. By November of 1944, fighting between the GMD garrison forces and local guerrillas had engulfed the entire Ili Valley, and the Provisional Government of the Eastern Turkestan Republic (ETR) had been established in Gulja. ${ }^{2}$

For the people of the eight Sibe villages, situated just a half-day's journey and one

1. In the PRC's chronology of the liberation of Xinjiang, this marks the day when Burhan Shehidi, the Chinese Nationalist Party (GMD) provincial chairman in Ürümchi, telegrammed Mao to invite the PLA into the province. The PLA did not actually cross the border from Gansu into Xinjiang until October 12, and advanced units of the PLA didn't reach the Ili Valley until December of that year. Xu Yuqi 徐玉圻, Xinjiang Sanqu geming shi 新疆三区革命史 (A history of the Three Districts Revolution) (Beijing: Minzu chubanshe, 1998), pp. 238-39. This text will be abbreviated as HTDR.

2. Gulja, or Yining 伊宁市 in Chinese. Present-day Sibe, as well as historical sources written in the Sibe language, follow the local Turkic peoples in using the name "Gulja." An "Eastern Turkestan Republic" had previously been established in Kashgar during the early 1930s but was quickly crushed by a combination of Soviet and warlord troops. 
ferry ride away from Gulja, the founding of the new government and its ongoing military campaign against GMD rule across all of Xinjiang only added to the uncertainty and danger that had characterized life since the fall of the Qing in 1911. However, it also presented opportunities for local people to take greater control over the affairs of their community. This paper will investigate the actions the Sibe community took in response to the sudden collapse of GMD control—control that the Nationalists had only just wrested from the last of a series of Han Chinese warlords who had ruled Xinjiang for thirty-two years. Among the most salient actions undertaken by the Sibe community was the establishment of the Sibe Cavalry Company at the request of the provisional government. This unit joined the official army of the ETR government and fought on the central front of the war against the GMD.

Three veterans of the Sibe Cavalry Company, Ujalan Liyanšeng, Funggantai, and Wu Haomin 吳浩民, published their memoirs in 1987, 1990, and 1993, respectively, and translations from these accounts will form the basis of this paper. ${ }^{3}$ The first memoir was published in the Sibe language, the second in Chinese, and the third was written and published in Uyghur. These three accounts are the only eyewitness records of the Sibe Cavalry Company that have been published. Taken together, they represent the largest and most complete first-hand description of any unit in the ETR army that exists in any language. These documents, although separated from the original events by nearly forty years and filtered through the official language of the People's Republic of China, contain important details on the experiences of soldiers, the progress of battles, and the overall tactics and organization of a local military force that successfully established de facto independence across northern Xinjiang.

Over the course of two research trips to Xinjiang in 2006 and 2007, I conducted interviews with elderly Sibe who had lived through the ETR period as well as Sibe academics and editors. Among the Sibe I interviewed was Šumutong, who, from 1946 to 1949, served as the magistrate of Sumul County (the administrative unit that included the eight Sibe villages and is currently known as Cabcal County). Šumutong was among the first Sibe to join the ETR military forces in November of 1944 and served as an intelligence officer and translator on the general staff. In this capacity he was personally involved in the formation of the Sibe Cavalry Company. ${ }^{4}$ Information gathered during these interviews, in combination with examination of the Sibe veterans' memoirs and other published sources, takes us a step further towards understanding what motivated

3. Ujalan Liyanšang 吴连胜, Sibe moringga liyan coohai ejebun (Memoir of the Sibe Cavalry Company) (Ürümchi: Xinjiang renmin chubanshe, 1987); Wu Haomin, "Šive atliq iskadroni heqqide eslime" (True Memoir of the Sibe Cavalry Company), Sinjang Tarikh Matiriyalliri 35 (1993): 49-91; Feng'antai 丰安太 [Funggantai], "Guanyu Sanqu geming Xibo qibing lian de pianduan huiyi” 关于三区革命锡伯骑兵连的片断回忆 (An incomplete recollection of the Sibe Cavalry Company during the Three Districts Revolution), trans. Ying Lin 英林, Yili wenshi ziliao 伊犁文史资料 6 (1990): 95-108.

4. Šumutong generously granted two long interviews and also agreed to be recorded singing the Sibe song commemorating the Sibe soldiers who died in battle in 1945, as well as the song of the "Alcohol Revolution." As a young man, Sumutong received an extensive education in the USSR, attending gymnasium in Almaty and university in Tashkent. 
young men in Xinjiang to take up arms against Chinese rule and towards understanding the complex relationships among the various ethnic groups who joined the ETR cause.

Issues of motivation and ideology are all the more curious when we consider that the Sibe did not share many of the religious and historical grievances towards Han Chinese or China-based states held by the Uyghurs and Kazaks. Historically, Sibe selfdescriptions had been bound to their status as bannermen, sent west to protect the territorial integrity of the Qing empire in Central Asia. A rebellion like that embodied by the ETR was precisely the kind of thing that the Sibe were supposed to prevent. It is also quite conceivable that the Sibe could have sat out the war and remained warily in their stockades, as they had attempted to do during many of the other upheavals of the preceding hundred years, such as the Muslim rebellions of 1864-1871 and the violence that attended the final collapse of the Qing in 1911-1913.5

Yet the Sibe Cavalry Company not only fought but also was tasked with executing some of the most dangerous assaults that the ETR's National Army (INA) would bring against GMD military positions. The Sibe fought in two major battles: first, the defense of Yongjihu永集湖 in June of 1945; and second, the attack on the fortified town of Jinghe精河 two months later. By the conclusion of the second battle, casualties had cut the Sibe company's strength nearly in half. The company fought on, however, well into 1946. Why did some Sibe take up arms on behalf of the new and fragile government of Eastern Turkestan? How was this revolution understood during the 1940s? How has it been remembered subsequently?

During the course of my research in Xinjiang, I was unable to locate any primary sources generated by Sibe or about Sibe during the period in question. As a result, the first section of this paper will address these questions on the basis of memoir literature produced by Sibe memoirists and historians since 1979. In order to do so, however, it is necessary to situate these works within the greater context of writing about the ETR in the People's Republic of China. Since 1949, the PRC has endeavored to create and sustain an official history of the ETR that is dramatically different from the narratives that have survived in the popular memory of non-Han residents of Xinjiang and in their

5. Several sources provide a Sibe perspective on the upheavals of the 1860s-1870s. An 1871 report on the situation among the Sibe banners from their commanding officer, Karmangge 喀爾莽阿: see Mujingga 穆精阿, trans., Yili Xiboying zongguan Ka-er-mang-a fen cheng shu Yili jiangjun Wuliyasutai jiangjun Tacheng canzan dachen daizou zhi bingtie 伊利錫伯營總管 喀爾莽阿分呈署伊利將軍烏里雅蘇臺將軍塔城參贊大臣代奏之禀帖 (Unpublished manuscript in collection of He Ling 贺灵, 1958). The account of the Sibe bannerman Bališan collected by the Russian Sinologist/Manjurist Diyakhov in 1905; an unpublished Chinese-language translation of the Russian translation of this text has recently been produced by Tong Yuquan 佟玉泉. A third pre-1911 Manchu-language account of the Muslim rebellions is found in the document titled Yili shibian ji 伊利事變記 (Record of the Ili incident), in Xibozu minjian sancun Qingdai Manwen gudian wenxian 锡伯族民间散存清代满文古典文献, ed. Tong Yuquan and Tong Keli 佟克力 (Ürümchi: Xinjiang renmin chubanshe, 2008). Donjina (ca.1860-1930s?), a Dagur from Heilongjiang who participated in the reconquest of Xinjiang in the 1880s, also left a substantial account of banner society in Ili during the late Qing: Donjina-i sabuha donjiha ejebun (Donjina's memoirs of things seen and heard) (Ürümchi: Xinjiang renmin chubanshe, 1988). 
oral histories and literature. An examination of Chinese official and academic literature will show that it employs an explanatory framework that increasingly denies that nonHan ethnic groups ever played a proactive role in the history of the region, certainly not one that could have ever led to an independent state, and places obstacles in the path of understanding the ethnic and religious origins of the ETR movement. Ujalan Liyanšeng and Wu Haomin each wrote histories that in form support and in substance subvert the official narrative, and these divergences offer glimpses of what "revolution" might have meant to the Sibe of 1944.

In the second half of the paper, I offer a narrative of the Sibe cavalry company's involvement in the military campaigns of 1945-1946 assembled from both the oral and written histories of the period. This section will argue that the revolution of 1944 was first understood within the Sibe community primarily in the context of previous incidents of ethnic violence in Xinjiang. As the ETR movement evolved over the course of the fall and winter, so did the Sibe's understanding of the movement. The eventual decision of Sibe banner officials to commit troops to the ETR was based on a political assessment of the relative advantages of participation and also on the basis of more subjective issues relating to the centrality of military service to their community's conception of ethnic identity.

Previous western scholarship on the ETR has been preoccupied with political questions. The focus has been on the larger political agenda of the ETR, especially the matter of whether the ETR movement was an independence movement, and on the question of whether it was the USSR that instigated and mobilized the rebellion in Ili. The preoccupation with these issues has distracted scholars of Xinjiang history from examining other historical changes and social issues relevant to the lives of ordinary residents of Xinjiang. Moreover, the questions usually asked of the 1940s are highly reductive. This essay will argue that many of the individuals who witnessed the events of the 1940s did not understand these events in terms of stark binaries of independence verses national unity or class conflict. From the fall of the Qing dynasty through the early 1950s, the political landscape in Xinjiang was complex. The political goals and ideology of the ETR, such as it is visible through the limited available sources, were throughout the existence of the movement very much a "work in progress." Such shifts reflected multiple transitions of personnel within the leadership of the ETR as well as evolving Soviet foreign policy towards the Nationalist government of China in the context of the first the Second World War and subsequently the Chinese Civil War. One can easily imagine that from the perspective of the Sibe communities to the south of the river, interpreting the goals and agenda of the ETR, in addition to those of the other major players in the region such as the Soviet Union and the Chinese Nationalists, was an extremely difficult and fraught endeavor.

In this paper, by focusing on the Sibe communities during the ETR period, it is 
easier to see that social and political tensions in Xinjiang were as much about dealing with the legacies of the Qing empire as they were about the rise of Uyghur or Kazak nationalisms. In what follows, I hope to show that the events of the 1940s, in particular debates within the Sibe communities about whether to commit troops to the ETR's military forces, reveal the extent to which Sibe were still grappling with their identity as bannerpeople in a post-imperial landscape.

\section{The Eastern Turkestan Republic in Historical Discourse}

The history of the Eastern Turkestan Republic is one that the Chinese government probably wishes it did not have to write. The successful establishment of a de facto independent state of Uyghurs, Kazaks, and other non-Han ethnic groups with a governing ideology that at times embraced overtly separatist and religious goals set a precedent that many Chinese academics would prefer to see forgotten. In this sense, the official history of the ETR fits into the larger trend of official PRC scholarship on Xinjiang since the 1990s that suppresses any evidence that the region was ever independent for any period since the Han dynasty. ${ }^{6}$ Yet the centrality of the ETR in the memory of Xinjiang's minority ethnic groups, and its persistent appearance in the historical narratives of Uyghur and Kazak nationalists, has forced the government to repeatedly address the period in question. In the early 2000s, for instance, the Uyghur writer Zordun Sabir's three-volume historical romance about the ETR, Motherland, was probably the most widely read piece of fiction in Uyghur culture. ${ }^{7}$

On the eve of the Communist takeover of Xinjiang, the CCP propagandists began to construct what would become the standard narrative of the Eastern Turkestan Republic. Mao's first official telegraph to ETR leadership attempted to place the ETR firmly within the chronology of CCP-approved events that were about to culminate in the Party's reunification of China. "Your long years of struggle," Mao wrote, "are one part of our entire Chinese country's democratic revolutionary movement." ${ }^{8}$ Moreover, in the same telegram, Mao pointed out that, regardless of the ETR's achievements in Xinjiang, their "complete liberation" required the assistance and tutelage of the CCP. This narrative downplayed the role of "splittist" Turkic nationalists or religiously minded ETR leaders, celebrated those officials of lower-class backgrounds who advocated the unity of Xinjiang with China and socialism (or at least the selected statements of such officials), and placed the event firmly within the story of the CCP's own struggle against the "exploitative classes," American imperialism, and the authoritarian government of

6. Gardner Bovingdon, "Contested Histories," in Xinjiang: China’s Muslim Borderland, ed. S. Frederick Starr (Armonk, NY: M.E. Sharpe, 2004), p. 355.

7. Zordun Sabir, Ana Yurt, 2d ed. (Ürümchi: Šinjang yašlarösmürlür näšriyati, 2000).

8. Telegram of August 18, 1949, in HTDR, 229. 
the GMD. Subsequently, PRC propaganda (television and radio broadcasts, as well as newspapers and magazines intended for the general public) has studiously avoided using the term "Eastern Turkestan Republic" and refers to the period merely as the "Three Districts Revolution," thus eliminating any impression of statehood or the existence of a functioning government.'

The government-sanctioned effort to write the official history of the Three Districts Revolution did not begin, however, until an editorial committee was established for that purpose in Gulja in $1988 .{ }^{10}$ The products of this committee's efforts started to emerge in the late 1980s and early 1990s. Of these, the multivolume Record of Major Events of the Three Districts Revolution (1994) and the related, shorter summary, History of the Three Districts Revolution (HTDR, 1998) are the most important and widely available. ${ }^{11}$ These two works develop Mao's original premise into book-length form. In these accounts, autocratic rule by warlords and the GMD, economic exploitation, and EuroAmerican imperialism set the basic conditions for the uprising. Yet in addition to these standard themes, these official publications also addressed the Soviet Union's involvement in the Three Districts Revolution - a topic that had previously been avoided. ${ }^{12}$

The publication of the official line on the ETR provided Chinese academics with a framework to begin their own studies, and a small body of academic literature has subsequently been published in the PRC. These individual academic works share with the official narrative the premise that Soviet-trained Uyghur and Kazak agents, together with their Soviet advisors, were primarily responsible for the outbreak of anti-state violence and that they did so by manipulating the religious beliefs and nationalism of the common Turkic people of Xinjiang. In explaining the different methods by which the USSR instigated the revolution, HTDR states, "[The USSR] created public opinion .... It utilized easy-to-swallow slogans about ethnicity and religion to arouse the masses." ${ }^{13}$ Cao Guofang's曹国芳 article about Soviet actions on the eve of the Ili uprising states the case for blaming the USSR most strongly. He writes, "Step by step, the USSR implemented invasive and subversive activities to sow discord and thus caused the social and political situation in Xinjiang's border regions to become increasingly nervous, chaotic, and agitated." ${ }^{4}$ The Chinese verb liyong 利用, “to manipulate," is

9. The three districts were Ili, Targhabatay, and Altay.

10. Much of the following information on the history of ETR-related publications was collected during personal interviews conducted in Ürümchi on August 3, 6, and 13, 2007. For further historiography, see David D. Wang, Under the Soviet Shadow: The Yining Incident, Ethnic Conflicts and International Rivalry in Xinjiang, 1944-1949 (Hong Kong: The Chinese University Press, 1999), p. 7. The post-script to HTDR also contains a brief account of the committee's work.

11. By "widely available," I mean that these books can be found in major government libraries in Xinjiang (such as the Xinjiang University Library and the collections of the Xinjiang Academy of Social Sciences) and are frequently cited by mainland authors. A search of Ürümchi bookstores in August of 2007, however, turned up no copies of these books in either Chinese or Uyghur.

12. Personal interviews; Wang, Under the Soviet Shadow, 13.

13. HTDR, 13.

14. Cao Guofang, “Sulian yu Sanqu geming qianxi Xinjiang bianjing diqu de shehui zhengzhi jushi” 苏联与三区革命前夕 
used consistently in the literature and in combination with a network of even more loaded terms such as yinyou 引誘, "to seduce," strips the non-Han residents of the Three Districts of any real agency in the events to follow. ${ }^{15}$ Hong Tao 洪濤, a professor of history at Xinjiang University, writes that the "counterrevolutionary" Elihan, "using religion as a pretext, went among the people spreading rumors." ${ }^{16}$ This type of language reflects a reluctance to address religion as a serious motivating factor for either ETR leaders or the common people.

Official writing on the ETR is also typical of the larger body of official works on Xinjiang's history in which non-Han ethnic groups play a passive and subjective role, while the Han are the progressive party, pulling the reluctant minorities towards modernization. Gardner Bovingdon labels this framework "Marxism-Nationalism." $\mathrm{He}$ writes that official historians "make use of Marx's analysis of social formations to argue that Hans had achieved an advanced level of civilization before the 1949 Revolution, while Uyghurs and other non-Hans lagged far behind." ${ }^{17}$ From this perspective, the uprising in Ili naturally was either the work of the Soviets or the Chinese Communist Party. This framework implies that minority groups inherently lack initiative and purpose. Chinese official sources systematically preface actions taken by ETR leaders with phrases like "under the influence of Soviet advisors" or "with the help of USSR experts." In describing the opening of the ETR's attack on the GMD controlled town of Jinghe, for instance, the HTDR states, "The vice-commander of the Ili forces, Ishaq Beg, under the assistance of Soviet advisors led [the troops into the attack]." ${ }^{18}$ In other cases, Chinese academic literature divides the native leaders of the ETR into "tamed" and "un-tamed," with the latter referring to the "nationalist" leaders who "pulled the movement in the wrong direction." 19 Taken to the extreme, this framework underlies the argument in David Wang's book that states that the Gulja government and its nonHan supporters were merely the "docile pawns" of the USSR. ${ }^{20}$

Since the opening of communications between the ETR and the CCP in the summer of 1949, Communist officials have attempted to transform popular memory of the Three Districts Revolution by asserting their own hegemonic narrative of history. Yet

新疆边疆地区的社会政治局势 (The Soviet Union and the social and political situation in the Xinjiang border region on the eve of the Three Districts Revolution), Beijing keji daxue xuebao (shehui kexueban) 北京科技大学学报 (社会科 学版) 2005.4: 123.

15. Cao, "Sulian yu Sanqu geming qianxi," 124.

16. Hong Tao, “Lun Ahemaitijiang, Abasuofu fandui Ailihan Tulie fenlie zuguo de douzheng” 论阿合买提江、阿巴索夫反

对艾力汗 - 吐烈分裂祖国的斗争 (On the effort by Ahemaitijiang and Abbasoff to fight against Ailihan Turei's separatism), Xinjiang daxue xuebao (shehui kexue ban) 新疆大学学报 (社会科学版) 2004.3: 73. See also Xue Xiantian 薛衔 天, “Shilun minzu yinsu dui Sulian tiaoting Sanqu geming de yingxiang” 试论民族因素对苏联调停三区革命的影响

(Discussion of the influence of ethnic factors in the USSR's intervention in the Three Districts Revolution), Zhonggong dangshi yanjiu 中共党史研究, 2003.1: 69.

17. Bovingdon, "Contested Histories," 356.

18. HTDR, 80.

19. Xue, "Shilun minzu yinsu," 74.

20. Wang, Under the Soviet Shadow, 18. 
in practice, the state's narrative has been mediated through authors and editorial committees, and even those writers who are sympathetic to the state's goals have changed the narrative in significant ways. In recent years, and especially since 2001, Chinese academics writing about the ETR have increasingly relegated Mao's positive spin on the movement to a formulaic opening sentence. The register of the language employed in these articles has shifted, and words with positive connotations in Chinese have been increasingly replaced with negative words that suggest the Three Districts Revolution was fundamentally a "chaotic" (luan乱) and destabilizing event. ${ }^{21}$ As I will discuss in the next section, the state's need for writers to convey its message to the people has provided Sibe authors with a forum to keep their own history and language alive. The three Sibe memoirs examined for this essay are products of this process. The following section will consider ways in which the ethnic Sibe authors have altered the official narrative of Xinjiang's history and imbued it with other meanings.

\section{Sibe Authors and the History of the Eastern Turkestan Republic}

The Sibe are prolific writers of their own history, publishing well over a hundred books on the subject between 1981 and 1995 alone. ${ }^{22}$ This is a reflection of the centrality of history in the construction of contemporary Sibe self-understandings, particularly for the approximately 40,000 Sibe who live in Xinjiang. The Sibe look back at the history of their migration from Manchuria in 1764-1765 to explain their incongruous presence beside the ten million Uyghur and Kazak residents of the province.

In 1764, the Qianlong emperor dispatched 1,020 Sibe military households to the Ili Valley in order to strengthen the Qing empire's defenses in Central Asia. The Sibe settled on the south bank of the Ili River in what is now know as Cabcal County. The broad and temperate Ili Valley is located in the far northwest corner of present day Xinjiang, straddling the border with Kazakhstan. The northern and southern arms of the Tianshan Mountains seal the valley from the Chinese interior to the east and forced the Ili River to meander westward into the Kazak steppe. The communications and economy of the valley were thus naturally oriented to the west, creating ideal strategic conditions for either invaders from the western Eurasian steppe or (in the case of the ETR) for local rebels. The Sibe garrisons helped plug this dangerous gap on the Qing border.

The anniversary of their arrival in Ili is celebrated officially by the PRC and is portrayed in official publications as an example of the Sibe's "great contribution to the

21. See for example, Cao, "Sulian yu Sanqu geming qianxi," 127.

22. See for bibliography He Ling, Tong Keli 佟克力, and Tong Yuquan 佟玉泉, Xibozu baikequanshu 锡伯族百科全书 (The encyclopedia of the Sibe) (Ürümchi: Xinjiang renmin chubanshe, 1995), pp. 20-547. 
motherland." Historical works on the Sibe authored by committee or individual authors are framed by the description of the Sibe's efforts towards preserving the unity of the Chinese nation. ${ }^{23}$ The Sibe involvement in the ETR is also placed firmly in this framework. A newsletter published by the Xinjiang Sibe Language Study Society, collected at the "Western Migration Festival" on April 18, 2006, provides a representative summary of Sibe history. A sub-heading labeled "The Sibe protect the unity of the motherland and oppose foreign invasion" included descriptions of both Sibe soldiers' participation in Qing-era campaigns against Turkic Muslim rebels and their participation in the ETR campaign against the GMD. ${ }^{24}$

Ujalan Liyanšeng, Funggantai, and Wu Haomin composed their memoirs at the same time as PRC officials in Xinjiang and Beijing were producing the official history of the ETR as well as other major official histories of Xinjiang and the Uyghurs in general. ${ }^{25}$ With the exception of Liu Zhixiao's 刘志霄 planned three-volume History of the Uyghurs, these official histories were all written by committees composed primarily of ethnic Han scholars and are characteristic of the "Marxism-nationalism" framework described above. ${ }^{26}$ A year and a half prior to the publication of Ujalan Liyanšeng's Memoir of the Sibe Cavalry Company, the official history of the Sibe ethnic group, the Concise History of the Sibe was published in Chinese. ${ }^{27}$ Thus the Sibe memoirists, as well as their editors, had several model pieces of historical writing to work with when they began writing.

Versions of the Concise History of the Sibe were circulated internally in the government as early as the 1960s. It is unclear what changes were made when the volume was finally published in 1986. The account of the Three Districts Revolution in the Concise History of the Sibe hews very closely to the Mao-approved line as it existed before the Xinjiang government's official committee began publishing its results. The author, Xiao Fu 肖夫, first introduces the ETR in a stand-alone paragraph that simply states, "The Three Districts Revolution of 1944 also occurred under the influence of the Chinese

23. It is important to point out that in the PRC literature, the Sibe are never "establishing" the unity of the motherland, rather they are only "protecting" and "defending" the nation. The implication here is that the Chinese nation never expanded into Xinjiang; rather, it was always there.

24. Ding Lijun丁立军, “Xinjiang Xibozu dui zuguo de weida gongxian” 新疆锡伯族对祖国的伟大贡献 (The great contribution of Xinjiang's Sibe to the motherland), Xinjiang Xibozu yuyan xuehui xuehui tongxun新疆锡伯族语言学会学会 通讯 15 (2006): 11-13.

25. For example: Liu Zhixiao 刘志霄, Weiwu'erzu lishi 维吾尔族历史 (The history of the Uyghurs) (Beijing: Minzu chubanshe, 1985), vol. 1; Xinjiang jianshi 新疆简史 (Concise history of Xinjiang) (Ürümchi: Xinjiang renmin chubanshe, 1987); and Weiwu'erzu jianshi 维吾尔族简史 (Concise history of the Uyghurs) (Ürümchi: Xinjiang renmin chubanshe, 1989).

26. Bovingdon, "Contested Histories," 360-62.

27. Xibozu jianshi 锡伯族简史 (Concise history of the Sibe) (Beijing: Minzu chubanshe, 1986). The Sibe language edition of this work was published in 1993 and contains much greater detail than the Chinese language edition and runs to 496 pages (the Chinese-language edition is 145 pages). According to editors at the Xinjiang People's Press, an earlier Sibelanguage version of the Concise History was published in the 1980s that contained an even greater degree of detail than the 1993 edition. Following the tightening of censorship practices in the 1990s, however, this content was deemed too sensitive and was struck from the newer Sibe-language edition. Interviews, August 3, 2007. 
Communist Party." ${ }^{28}$ From this point on, however, Xiao Fu's narrative makes no subsequent mention of any connection between the actions of the Sibe in Cabcal or ETR leaders and the Communist Party. Ujalan Liyanšeng and Wu Haomin, the two veterans of the Sibe cavalry troop, take a similar approach: both open and close their works with language that matches the official PRC interpretation almost word for word, yet, as will be discussed below, the main bodies of their texts introduce alternate explanations. In interviews, editorial staff of minority publishing units in Xinjiang admit that formulaic introductions and conclusions are required but also point out that these formulaic sections, paradoxically, can also allow authors to take certain liberties with their texts. ${ }^{29}$

The memoirs were written during a period of relative freedom for minority-language publishing in Xinjiang. ${ }^{30}$ During this period of literary détente, minority writers published an unprecedented array of historical accounts in their own languages, and, although the vast majority of these works steered clear of any direct controversy, a handful challenged the ideology of the official histories. ${ }^{31}$ Among these new publications were a number of memoirs that tackled the pre-1949 period, and this reflected the convergence of the great public interest in the ETR and the fact that the ETR and early PRC generation of politicians and intellectuals were aging and retiring.

The Sibe memoirists were deeply concerned that their story would be forgotten. Ujalan opens the first chapter of his book with the statement calling the Sibe soldiers a "generation buried by clouds and fog." ${ }^{2}$ Their concern does not seem misplaced when one considers that in the official account (i.e., $H T D R$ ) the name of the unit appears only once in a list of other units of the ETR army and there is no additional description of either the unit's formation or other contemporary events in Cabcal. ${ }^{33}$ According to contemporary Sibe intellectuals and interviews with Sibe government employees in Cabcal, few Sibe still know that Sibe cavalry forces participated in the ETR movement, and the monument erected to commemorate the Sibe soldiers who died in the conflict may not exist any more. ${ }^{34}$ Wu Haomin also may have published his account in Uyghur because he was much more likely to find a larger audience among the Uyghurs, who are the most avid readers of ETR-related history. ${ }^{35}$

28. Xibozu jianshi, 73.

29. Interviews, August 11 and 14, 2007.

30. According to Bovingdon, this period came to a close in the early 1990s after the Baren Incident and the collapse of the Soviet Union. Gardner Bovingdon, Autonomy in Xinjiang: Han Nationalist Imperatives and Uyghur Discontent, Policy Studies 11 (Washington, DC: East-West Center, 2004), p. 30.

31. A prominent exception being Turghun Almas's The Uyghurs. See Bovingdon, Autonomy in Xinjiang, and Wang, Under the Soviet Shadow.

32. Ujalan, Sibe moringga liyan coohai ejebun, 1.

33. HTDR, 80.

34. Anonymous interviews, August 8 and 14, 2007; Sumutong, interview, August 15, 2007. Šumutong believes that the monument no longer exists. On a personal trip to Jinghe County (the location of the monument) in 2007, I was unable to ascertain the status of the monument.

35. He also may have chosen to publish in Uyghur because many educated Sibe of his generation would also be fluent in Uyghur. In fact, more Sibe of that generation might be literate in Uyghur than in their own language. 
Wu Haomin's True Memoir of the Sibe Cavalry Company (1993) appeared in the Uyghur language version of the Xinjiang Historical Materials (Sinjang Tarikh Matiriyalliri) series published by the Xinjiang People's Political Consultative Congress Historical Materials Committee (XJ PPCC). This serial began first by publishing articles in Chinese, and a Uyghur-language edition soon followed in the mid-1980s. It has been one of the main venues for publishing historical memoirs and research in Xinjiang. Significantly, several volumes have been devoted to the ETR, and articles that touch on this event appear in nearly every volume for the first decade of publication. According to Ai Jinxun, the current director of the XJ PPCC, their ability and willingness to publish on this subject is partially on account of the serial's designation as an "internal circulation" publication. Since the series is not designed for public consumption, it does not have such strict editorial controls. The committee's mandate to document history (in particular, collect memoirs) and create a repository of information for use by government researchers has meant that the series has included material that the popular press would avoid as too sensitive, unmarketable, or requiring extensive editing. ${ }^{36}$ The series is valuable not because it allows us a glimpse of secret and unadulterated primary sources (which it does not), but rather because it promotes the production of memoirs that would otherwise not exist in Xinjiang's current publishing climate. In the experience of this researcher, certain memoirs published in the series are more candid and detailed than related works that appear in the popular press, yet they still pale in comparison with the "raw," unedited recollections that come across during personal interviews.

In this case, the memoirs by Funggantai, Wu Haomin, and Šumutong, which all appeared in "internal circulation" serials, are more detailed than Wu Liyanšeng's original 1987 memoir, which was released to the general public. The dates and place names correspond much more closely to other accounts of the Three Districts Revolution, including the official History of the Three Districts Revolution. ${ }^{37}$ Šmutong's account is written very much in the first person. This reflects the fact that, as a relatively wellknown individual who wielded considerable power, he had a much more significant role in the making of the history he recounts. Wu Haomin and Funggantai, to a lesser degree than Šumutong, also describe their individual actions and experiences. Wu describes his personal duties during the campaign, first as a medical orderly and later as a member of the regiment-level propaganda team, translating information on the Sibe troops into Uyghur. A separate biography of Wu states that after the Sibe cavalry had returned from the front in August 1946, he rose to the rank of lieutenant in the internal affairs department of the ETR government. After 1949, he had a long career in the

36. Interview, August 14, 2007.

37. Wu Haomin is identified in the Historical Materials series as being from the "Ili Sibe Military Region," which may be a reference to a specific military sub-headquarters. Thus he may have had more direct access to military archives from the ETR. Editors I spoke with confirmed that Wu worked from archives and not merely from memory when preparing his account but did not know which specific archive(s). 
PLA and, from 1981 on, served as an advisor in the Ili military district. Thus he seems slightly better placed to have observed the officers of the unit and speaks about the overall organization of the ETR army, its strategy, and politics with more certainty and detail. Funggantai was the company quartermaster and his account provides a lively personal narrative of what was going on just behind the front line of battle. His account is also much more attuned to the logistical details that made the company function. Ujalan Liyanšeng served as a common cavalryman in the first platoon of the Sibe Cavalry Company. In contrast to the other accounts, however, he never writes himself into his text and narrates more from the generalized perspective of the average soldier. His account is more emotional, stressing repeatedly the difficulty of parting, the feelings of homesickness among the soldiers, and at many points a sort of general wonder at the carnage of battle.

The memoirs all tread the fine line between historical memoir and historical fiction. Dramatic descriptions of the landscape, battles, speeches, and meetings are all given an air of verisimilitude when combined with the authors' own personal observations and other historical details. That both works share significant similarities with the genre of historical fiction is unsurprising given the centrality of the genre in Xinjiang. Historical fiction flourished during the 1980s and continues to be one of the main ways in which minorities in Xinjiang, particularly the Uyghurs, write about history. In the absence of convincing official historical accounts in either Chinese or Uyghur, historical novels have become a repository of "real" history in popular culture. ${ }^{38}$ This is true for the Sibe as well. The largest and most widely available work on Sibe history is Guo Jinan's Convey a Beautiful Name to the Future, a massive novel describing the Sibe migration to Xinjiang. ${ }^{39}$ Ujalan's 1987 book is the most dramatized of the various accounts. Yet even Wu Haomin's article, intended for an ostensibly objective historical publication, includes invented dialogue and descriptions of the private thoughts of individuals other than the author. The dramatization of history and the implicit understanding on the part of the writer, editor, and reader that certain elements are fictional provides room for the authors to insert events, ideas, and speech into their texts that do not appear in other contemporaneously published official histories.

It should also be added that in the 1980s and early 1990s minority-language publications, on account of their incomprehensibility to most ethnically Han editors and censors, often slipped through with taboo content. According to interviews with editors in

38. Bovingdon, "Contested Histories," 369-71; and Justin Jon Rudelson, "Uighur Historiography and Uighur Ethnic Nationalism," in Ethnicity, Minorities, and Cultural Encounters, ed. Ingvar Svanberg (Uppsala: Centre for Multiethnic Research, Uppsala University, 1991), pp. 63-82.

39. Guo Jinan 郭基南, Saikan gebu amgade ulabumbi (Convey a beautiful name to the future) (Ürümchi: Xinjiang renmin chubanshe, 1991). This work has also been published in the Chinese edition as Liufang 流放 (Ürümchi: Xinjiang renmin chubanshe, 1993). The author was the county magistrate of Cabcal in the 1950s. This historical novel was completed in 1991 and describes the migration and settlement of the Sibe in Ili. 
Xinjiang, during the 1980s and 1990s editorial protocols in Xinjiang were not as rigorous, and ethnic minority editors were allowed more personal discretion in their work. ${ }^{40}$ Neither Ujalan's book nor articles published in the Historical Materials series were subject to the type of scrutiny that is currently leveled at all writings on minority issues.

Sibe authors have used a variety of strategies to write about the ETR. All of the works addressed in this essay have constructed their narratives behind the façade of the official line and the official language on the Three Districts Revolution. In all written accounts, the ETR is assigned its due place within the Chinese nation's "New Democratic Revolution" (新民主革命) under the leadership of the Chinese Communist party. Yet despite having to write within the constricts of Mao's framework, Sibe authors have produced descriptions of the ETR period that valorize the Sibe soldiers and depict a community that was quite capable of undertaking dramatic social changes on its own initiative. In the preface to the Chinese-language version of Ujalan's memoir, one short passage succinctly demonstrates how quickly a key phrase from government propaganda can be subtly subverted: "Our country is a nation-state constituted from many ethnic groups. Each of these ethnic groups has their own history of revolutionary struggle and all of them made a contribution to our ancestral country's liberation and unification." ${ }^{11}$ These accounts portray a period when ethnic sentiments-not class sentiments - ran high, and through conspicuous absences suggest that the Chinese Communist Party, its ideology, and the Han in general had very little to do with the "revolution" as it unfolded in Ili. Wu Haomin closes his memoir by characterizing his fight against the GMD as "a war for ethnic freedom." 42

Ujalan Liyanšeng and Wu Haomin also make a significant departure from the official line by situating the Three Districts Revolution firmly within the context of the USSR's war against world fascism (a word that is adopted directly into Sibe as fasis), not the Chinese war against Japan. The first chapter of Ujalan's book connects the Ili revolution to "World War Two" because it sought to destroy the government of Sheng Shicai 盛世才, the warlord who had turned against the USSR and allied with the GMD in 1942. Both his account and that of Wu Haomin are deeply oriented towards the war in the West (the European theatre), not the East. Ujalan's historical timeline begins with the German invasion of Russia, and Japan is first introduced in the context of the Pearl Harbor attack. In another striking omission, neither author mentions in any explicit way the effect their war against the forces of the Chinese Nationalists in Xinjiang might have had on the course of the civil war between the Nationalists and Communists elsewhere in China. ${ }^{43}$

40. Interview, August 3, 2007. See also Bovingdon, “Contested Histories,” 364-66, 369.

41. Wu Liansheng 吴连胜 [Ujalan Liyanšeng] and Tong Keli 佟克力, “Xibo qibing lian jishi” 锡伯骑兵连纪实 (Record of the Sibe Cavalry Company) (Unpublished manuscript, 2007), p. 1, emphasis added. This article has been contributed to the 2007 edition of the Yili wenshi ziliao, which has yet to be published.

42. Wu Haomin, "Šive atliq iskadroni heqqide eslime," 91.

43. Ujalan, Sibe moringga liyan coohai ejebun, 1-5. 
The Sibe memoirs of the ETR all manifest an interpretation of the past that is deeply at odds with the official framework. However, two important questions remain: How closely does their current ( $c a$. late 1980s-1990s) memory of the past correspond to the ways in which the Sibe of the 1940s understood the events transpiring around them? How has historical memory of Eastern Turkestan Republic evolved since the 1940s? In pursuit of answers, it is necessary to examine the documents—newspapers, government documents, official statements, and proclamations — extant from the ETR period for hints of what type of ideologies or ways of thinking were available to Sibe at that time. Unfortunately, a search for Sibe- or Manchu-language materials from Xinjiang during the 1930s and 1940s has located no extant documents. Therefore the discussion of the prevailing ideas and "isms" current in Xinjiang during this period will be based on the recent research of David Brophy, as well as the earlier research of Linda Benson and Andrew Forbes, who have investigated the intellectual climate visible in Turkic and Russian-language sources. This scholarship on pre-1949 Xinjiang provides evidence that the reasons for the revolution emphasized in the PRC's Mao-based interpretation do not represent all the ways people in Cabcal were thinking circa 1944. Contemporaneous documents presented by Brophy, Benson, and Forbes indicate that ethnicity, race, religion, and, above all, a deep-seated resentment of Han rule were as important to contemporary people as those motivations listed in PRC official publications. ${ }^{44}$

Interviews with Sibe who witnessed the events of the 1940s, as well as with Sibe who came of age shortly after 1949 and whose parents and other close acquaintances had witnessed the Three Districts Revolution, proved to be extremely useful in three ways. First, they provided details about events and society that either helped confirm or cast doubt on the existence of ideological claims or motivations during the ETR. Second, as will be discussed below, the interviewees suggested (often unintentionally) completely new ways of interpreting and remembering the ETR period that do not exist in written accounts. Third, they provided important historical details about language use, specifically the invention and deployment of key terms in Sibe relating to the idea of revolution, which allows the historian to establish a more accurate chronology of ideas and ways of thinking about revolution. In his Sibe-language memoir, Ujalan Liyanšeng uses five key words in his narrative of the Three Districts Revolution: uksura, "ethnicity" or "nationality"; dashalan, "revolution"; sulambusūn, "liberation"; irgejengge, "democratic"; and halambi, "to reform." Interviews revealed that, with the exception of the word uksura, Ujalan's use of these terms is anachronistic, as they did not exist in

44. David Brophy, "Tending to Unite? The Origins of Uyghur Nationalism” (PhD Dissertation, Harvard University, 2011); Andrew D. W. Forbes, Warlords and Muslims in Chinese Central Asia: A Political History of Republican Sinkiang 1911-1949 (Cambridge: Cambridge University Press, 1986), pp. 163-228; and Linda Benson, The Ili Rebellion: The Moslem Challenge to Chinese Authority in Xinjiang, 1944-1949 (Armonk, NY: M. E. Sharpe, 1989). See also Eric T. Schluessel, "Thinking Beyond Harmony: The 'Nation' and Language in Uyghur Social Thought," in On the Fringes of the Harmonious Society, ed. Trine Brox and Ildikó Bellér-Hann (Copenhagen: Nordic Institute for Asian Studies, 2014), pp. 323-27. 
the Sibe language in 1944. ${ }^{45}$ The concepts associated with these words, however, may have existed in Cabcal in some form or another in the fall of 1944, subject, as they are now, to a variety of conflicting uses and meanings. Many Sibe were fluent in Uyghur, Russian, and Chinese, and thus were exposed to a wider range of political ideas not yet translated into Sibe. Oral interviews and archival research thus demonstrates that during the 1980s, both Sibe memoirists had at their disposal frameworks for explaining the Ili rebellion that did not exist in 1944-1946.

It is the task of the following section to establish a narrative of the use of these terms and the concepts they embodied within Sibe culture. In so doing, I hope to whittle down the constellation of ideologies, identities, and mindsets that contemporary written and oral memoirs suggest as motivations for going to war or making revolution to the most historically likely ones. The discussion of these terms will be placed within a larger, "patchwork" narrative of the Sibe cavalry company cobbled together from both written memoirs and oral interviews conducted across Xinjiang. This narrative will demonstrate that ethnic self-understandings, honor and pride, and tangible economic and political gains were the most significant factors contributing to the Sibe will to fight. In the fall of 1944, the idea that they were participating in the great Chinese socialist revolution, or a socialist revolution of any shade, was foreign to all but a handful of Russian-educated Sibe activists.

\section{Sibe Society in 1944}

The establishment of the Eastern Turkestan Republic was accompanied by two months of protracted warfare around Gulja. Chinese Nationalist troops held out in isolated pockets around the city, and ETR guerilla forces were unable to completely secure the city until early January 1945. Although a small number of Sibe from the towns north of the Ili River participated in the initial rebellion, Sibe from Cabcal, the largest Sibe community in Xinjiang, did not participate in the fighting to capture Gulja. According to Šumutong, the sudden outbreak of violence caught most people by surprise and generated a great deal of fear within the Sibe villages. The early morning assault by Uyghur and Kazak guerrilla forces on Gulja on November 7 startled even the Sibe living in the city. Šumutong was in the midst of teaching class at the Gulja middle school when bullets came zinging past his classroom. He was more shocked, though, by the massacres of Han Chinese residents that began as soon as the rebels entered the city. By midNovember, this communal violence had extended its reach across the river into Cabcal.

45. Šumutong, interviews, August 5 and 16, 2007; anonymous interview, August 6, 2007. 
Bands of Kazak horsemen roamed the Cabcal countryside killing those Han Chinese or GMD officials that fell into their hands. The eight Sibe villages quickly mobilized for self-defense out of fear that this violence would turn against their own community. ${ }^{46}$

Within the Sibe language, the outbreak of violence in Ili was referred to as the hoise facubün, or "Muslim Chaos." This was the same term that had been applied to other outbreaks of violence that involved either local Turkic Muslims or Chinese Muslims (Chinese-speaking Muslims who had migrated from Gansu and Shaanxi). ${ }^{47}$ The term had already been applied to several previous rebellions during the twentieth century, the most recent being the uprisings of Turpanliks and Kumulliks (the Turkic speaking residents of the Turpan and Hami oases) during the early 1930s. Several officers of the Sibe Cavalry Company, including the unit's vice-commander Fuca Šingsan, had served in the army that put down those revolts. ${ }^{48}$

Sibe in Cabcal did, however, experience some beneficial changes due to the switch in government across the river. On the same day as the new provisional government of the Ili valley was established in Gulja, the name of the Sibe's home district was changed from the Chinese "Ningxi County” 寧西縣 to “Sumul County," and the new government appointed ethnic Sibe to important government posts in the county administration, including the position of county magistrate and vice-head of the police department. ${ }^{49}$ The use of the name "Sumul" by the new government in Gulja was clearly a nod towards the Sibe inhabitants of the district, as sumul is a term used by Turkic and Mongol inhabitants of Ili to refer to the niru, or banner companies that formed the basic administrative structure of Sibe society from the Qing dynasty through the 1930s. ${ }^{50}$

The eight Sibe settlements in Cabcal directly correspond to the eight original banner companies of military families that arrived in the region in 1765. Each niru (banner company) built a separate fortified village, and this string of eight niru ran east to west,

46. Šumutong, interviews, August 5 and 15, 2007. Šumutong was the first Sibe member of the secret People's Revolutionary Party, a group of Soviet-educated young men who, after returning to Xinjiang, had established the group in the early 1940s. According to Šumutong, the group included Exmet Jan Qasim, Saiffudin, and a number of other men who went on to become the core ruling group within the ETR government. Šumutong asserts, however, that at this stage they received no Soviet support - in fact the Soviet government found them an annoyance. The Soviets were more interested at this point in cultivating local nationalists and Muslim clergy who had greater standing and influence. In this case, the "revolutionary" party was in fact unaware that "revolution" was about to break out.

47. Anonymous interview, August 6, 2007. Donjina’s Republican-period account of Sibe history and culture for instance, refers to the late Qing Muslim rebellions in Xinjiang as the "Ili facuhūn": Donjina-i sabuha donjiha ejebun, 43.

48. Funggantai, "Guanyu Sanqu geming Xibo qibing lian de pianduan huiyi," 95.

49. Xibozu baikequanshu, 223-24.

50. Ujalan, Sibe moringga liyan coohai ejebun, directly uses the name "Eastern Turkestan Republic" (wergi turkistan gongheg'u) in the first part of his text to describe the political history of the movement. He then states (accurately) that the ETR officially gave up the name as part of the January and July peace accords of 1946 . For most of his narrative, he uses the term "Provisional Government of the Three Districts" (ilan ciui i taka dashalan i dasan yamun). The Sibe language reverses the Manchu words for east and west, with wergi meaning "east" not "west." 
loosely following the southern bank of the Ili River. ${ }^{51}$ The banner system, in practice, was embodied by the niru commandant, or janggin, whose job combined both civilian and military administrative duties and reflected the Sibe bannermen's joint roles as farmers and soldiers. The janggin was the main figure of authority in each Sibe niru and supervised household registration and marriage, the allocation of fields and residences, and the adjudication of legal disputes, in addition to maintaining the registry of troops and ensuring the military preparedness of the community. ${ }^{52}$

This highly militarized system of social organization persisted in Cabcal long after the collapse of the Qing dynasty. The two warlords who ruled Xinjiang after 1912, Yang Zengxin楊增新 (1911-1928) and Jin Shuren金樹仁 (1928-1933), both maintained the system, as it proved to be a reliable source of troops. Both of these warlords levied thousands of soldiers from among the Sibe banners over the course of the 1910s and 1920s. This was an extremely bitter period in Cabcal, to the extent that the population of the county began to decline. ${ }^{53}$

According to oral interviews with Sibe elders in the Seventh Niru, in the years before 1944, the Sibe villagers were living lives quite sequestered from the other ethnic groups around them. ${ }^{54}$ Within Sumul County, there were also large populations of Uyghur farmers and Kazak herders, but the different ethnic groups lived in separate communities and there was limited casual social contact with outsiders. This last point was particularly true for Sibe women. Knowledge of the Turkic languages was rare among the general public, although educated or well-off Sibe of elite families were generally familiar with Uyghur, Kazak, and Russian. ${ }^{55}$

There were, however, some important points of contact between the various ethnic communities. By the early 1940s, most niru contained one or two Uyghur-run dry-goods stores. Several interviewees recounted that contact with Kazak tribes was more cordial and common than with the neighboring Uyghur farmers. The Kazaks, for instance, often supervised the pasturing of Sibe-owned horses, cattle, and sheep in the Tianshan Mountains during the summer months. ${ }^{56}$ During the 1940 s, the Kazaks living in Cabcal County consisted mainly of two tribes: the Qizai, who inhabited the Wusun Mountains 烏孫山 and upper reaches of the Tekes River (in present-day Zhaosu County 昭蘇縣); and the Arba. According to Šumutong, the Arba had fled from Kazakhstan to Cabcal in the early 1930s to avoid collectivization. Although out-

51. The First and Third Niru settled together side by side and shared one fortified enclosure, creating one particularly strong bastion at the western end of the Sibe settlements.

52. Xibozu Baikequanshu, 182-83, 518.

53. Xibozu Baikequanshu, 182-83; Xibozu jianshi, 68-70. In 1949, only 11,486 Sibe lived in Cabcal, which represents only barely double the number of original settlers in 1764 .

54. Personal records from interviews conducted in the Seventh Niru, July 21-22, 2006. In these interviews, it was customary for the Sibe to use the term "taranchi" for the Uyghur farmers. See also Ujalan, Sibe moringga liyan coohai ejebun, 28.

55. Anonymous interview, August 6, 2007; interviews in the Seventh Niru.

56. Anonymous interview, August 4, 2007. Similar arrangements still exist today. 
numbering the Qizai, they had been forced to settle on the more marginal pastures in the steppe just south of the Sibe niru. Šumutong recalls that they were very poor and during the winter lived in temporary homes and caves on the edge of the Sibe villages. Many Sibe households took in Arba as servants or temporary laborers. There were also some rare incidents of intermarriage between Arba and Sibe. When war broke out in 1944, horsemen from the Arba tribe were responsible for many of the murders of Han civilians, yet they left the Sibe alone. ${ }^{57}$

In 1944, although residents of the Ili valley concurred that the region was inhabited by distinctive groups—Kazakh, Sibe, Taranchi (or for some "Uyghur")—-the day-today boundaries of the groups and the implications of these identifications were still up for debate. The Sibe were no exception. Even among themselves, Sibe increasingly disagreed over the implications of being "Sibe" or "people of the banners" (güsai niyalma). During the Qing dynasty, the Sibe's status as bannermen obligated to defend the Manchu court and its domains was central to their ethnic identity and sense of separateness. Rachel Harris writes that the fall of the Qing forced the Sibe to look for new ways to "legitimize their existence." 58 The Xinhai Revolution of 1911 was accompanied by a great deal of ethnic violence in Ili. Several of the Manchu garrisons on the north side of the Ili River across from Cabcal were massacred. The Sibe in their well-fortified and relatively self-sufficient villages on the opposite side of the river weathered the initial violence and appear to have been persuaded to join the revolutionary movement at an early stage. In 1912, two thousand Sibe troops fought with the Ili National People's Revolutionary Army (伊犁國民革命軍) against monarchist forces in Ürümchi. ${ }^{59}$

In the aftermath of the Xinhai revolution, a handful of Sibe who had been educated in Russia began establishing a range of new institutions in Ili that laid the foundation for a new Sibe self-understanding not beholden to their status as bannermen. ${ }^{60}$ In 1913, Salacun founded the Higher Studies Association (Shangxuehui尚学会) in Gulja to promote Sibe-language education with a modernized curriculum. In 1914, the association established a primary school in the First Niru that offered courses based on translations of Russian and Chinese textbooks. ${ }^{61}$ Over the next decade similar schools were established across the eight niru, and these schools provided a basic education in Sibe, Russian, and sometimes Chinese. However, this education was not universal and thus

57. Šumutong, interview, August 5, 2007; anonymous interview, August 4, 2007.

58. Rachel Harris, Singing the Village: Music, Memory and Ritual among the Sibe of Xinjiang, British Academy Postdoctoral Fellowship Monographs (Oxford: Oxford University Press, 2005), p. 32.

59. Xibozu jianshi, 68. In fact, the fighting between the Qing monarchist forces and the Ili Revolutionary Army took place along the same stretch of road between Gulja and Ürümchi as the fighting of 1945.

60. Prior to the Xinhai Revolution, the Qing banner authorities in Ili had dispatched several groups of Sibe to Russia for higher education.

61. Xibozu baikequanshu, 316; Xinjiang Xibozu renwulu 新疆锡伯族人物录 (Biographical dictionary of the Sibe people) (Ürümqi: Xinjiang Weiwu’erzu zizhiqu zhengxie wenshi ziliao weiyuanhui, 2001), pp. 40-42. 
most Sibe in 1944 were limited to the use of their own language. ${ }^{62}$ Many students from these schools went on to further education in Gulja and the USSR and later returned to found the second generation of Sibe cultural organizations during the 1930s. Among these was the Association for the Promotion of Sibe-Solon-Manchu Culture. ${ }^{63}$ It was also not uncommon for prestigious and wealthy families to send their children first to Gulja for primary school (usually at schools where the language of instruction was Chinese) and then later to middle schools and universities in Almaty and Tashkent. ${ }^{64}$ During the 1930s, Russian-educated Sibe served in positions throughout the government of Sheng Shicai and even as consuls in China's consulates in the Central Asian SSRs and in Siberia. ${ }^{65}$ Several of the Sibe who would take up official positions in the Sumul county government and on the staff of the Sibe Cavalry Company had received degrees from universities in the USSR. ${ }^{66}$

It was also members of this generation of educated Sibe who pushed most forcefully for the abolition of the banners. ${ }^{67}$ The survival of the banner system beyond the Qing and into the late 1930s generated considerable debate within the Sibe community, especially during the periods when the niru faced heavy demands for troops from Yang Zengxin and Jin Shuren. Yet, despite the absence of the Manchu empire, the military and labor service obligations that lay at the heart of the banner system remained at the core of Sibe identity. Interviewees consistently stressed the importance of farming or military service within Sibe society during the 1930s and 1940s. The reputation of each clan rested on the military service of its members and the clan's agricultural contribution to the general provisioning of both the home village niru and the soldiers in the field.$^{68}$ According to interviewees, the importance of service to the community in terms of either soldiering or farming outlived the official end of the banner system in 1938.

The end of the banner system was a watershed moment, changing not only the structure of local government but also the property relations and economic system of the niru. Sheng Shicai, the last warlord to rule Xinjiang (1934-1944), abolished the banner system, along with the traditional positions of banner and niru commandant,

62. Anonymous interview, August 6, 2007.

63. Xinjiang Xibozu renwulu, 55.

64. For an excellent description of one family's multi-generational interactions across the Russian/Soviet border, see Tong Keli 佟克力, “Xiboying Xianghuangqi Tongjiashi jiazu yu Eluosi wenhua jiaoyu” 锡伯营镶黄旗佟佳氏家族与俄罗斯文 化教育 (The Tong clan of the Bordered Yellow Sibe Banner and Russian education) (unpublished manuscript, 2007).

65. The life of Yindešan (1895-1960) is particularly illustrative. His family sent him to Almaty at the age of twelve to attend middle school, and he was so successful at his studies that he subsequently entered the University of St. Petersburg. He witnessed the Russian revolution and became personally acquainted with Frunze (during the Civil War, he would help reunite Frunze, of NKVD fame, with his sister who had fled to Xinjiang). He subsequently worked all across Asia as a negotiator and translator for various Chinese governments and was consul at Bishkek and at Qita. In 1960, he committed suicide after being labeled a rightist. Xinjiang Xibozu renwulu, 43-44.

66. Šumutong, interviews, August 4 and 15, 2007. The Xinjiang Xibozu renwulu also identifies a number of Sibe who studied in the USSR and even Tsarist Russia before 1949.

67. Xibozu jianshi, 68.

68. Šumutong, interviews, August 5 and 15, 2007; anonymous interviews, August 4, 6, and 14, 2007. 
and replaced it with his own system of administrators (and most importantly his own police network). The district was now formally known as Henan County 河南縣 with an administration modeled on Chinese county administrations in the Chinese interior. During the Qing, the land had been commonly owned by the banner company and allocated to individual Sibe households on the basis of need and labor resources. Since the fall of the Qing, however, individual families had begun to acquire long-term, customary rights to the land. Sheng Shicai formalized this trend and divided banner land into parcels of private property. Tax duties from this land were no longer delivered to the banner but rather directly to the Xinjiang government. The tax burden subsequently increased several fold. According to both Ujalan Liyanšeng and Wu Haomin, the onerous tax burden on the community only increased in 1943, when Sheng permitted the GMD to open party offices and take over the Cabcal garrison. ${ }^{69}$ The Encyclopedia of the Sibe states that by 1944 over twenty different types of taxes were levied on the community, and both Forbes and Benson concur with the local accounts that these levies, combined with inflation and the closure of the Xinjiang-Soviet border under ShengGMD rule, had devastated the economy of the Ili Valley. ${ }^{70}$

The Sibe held other complaints against Sheng's regime as well. During the latter part of the 1930s the warlord began arresting Sibe intellectuals whom he suspected of not supporting his regime. After he resumed an alliance with the GMD in 1941, pressure on Sibe activists increased, and a number of prominent Sibe intellectuals were executed on suspicion of their connections to the USSR..$^{71}$ Šmutong's father, Salacun, the founder of the Sibe Higher Studies Association and several-time consul at Xinjiang's consulates in Almaty, was arrested and jailed in $1944 .{ }^{72}$

Thus it is perhaps not too surprising that the new government of Sumul County worked quickly to dismantle Sheng Shicai's and the GMD's administrative system in November of 1944. It annulled the GMD tax system, opened the border with the USSR, and reinstituted important elements of the banner system, most importantly the positions of niru commandant (janggin) in the eight Sibe niru. Many of the older Sibe interviewed during the course of this research remember welcoming the return of the banner system. Cangdešan, a former banner official who had been in retirement in Gulja was appointed to the position of county magistrate and titled himself "amban" (specifically, lingdui dachen 领队大臣). The Sibe Eršan was installed as vice-head of the county police force and as the overall commandant of the Sibe banners (the ulhirida). ${ }^{73}$

69. Ujalan, Sibe moringga liyan coohai ejebun, 5; Wu Haomin, "Šive atliq iskadroni heqqide eslime," 49-50.

70. Xibozu baikequanshu, 233; Forbes, Warlords and Muslims in Chinese Central Asia, 164; Benson, Ili Rebellion, 35.

71. Among these was one of the founders of the Sibe-Solon-Manchu cultural association, Anziying. Anonymous interview, August 3, 2007.

72. Šumutong, interview, August 5, 2007. See also Xinjiang Xibozu renwulu, 41-42. Salacun was later released to the ETR government in late 1945 after complex negotiations.

73. Xibozu baikequanshu, 233. 


\section{The Formation of the Sibe Cavalry Company}

In January of 1945, following the final defeat of GMD units in the Ili Valley, authorities within the ETR government approached Sibe community leaders in Cabcal with the request to form a military unit. This move corresponded with the Gulja Declaration of January 5, 1945, in which the ETR government announced its intention to establish a regular "nationality army" (Ili National Army, INA). ${ }^{74}$ According to Wu Haomin, General Polinov of the general staff of the ETR army traveled to Cabcal with the Sibe members of his staff and called together a meeting of political and "intellectual" leaders and local notables from all eight of the Sibe niru. After prolonged discussions, the governing authorities of the Sibe banners decided to form and equip a Sibe cavalry unit. ${ }^{75}$ Ujalan recalls that the niru commandants (janggin) were then ordered to return to their home niru and call a meeting of the people in order to explain the reasons for creating the military force. ${ }^{76}$

The two-month gap between the opening of hostilities and the formation of the Sibe unit suggests that we cannot assume that the Sibe would naturally follow the other residents of Ili into rebellion and that the decision was carefully evaluated. During this period, GMD officials who fled into the Sibe niru received a variety of different treatments. The written memoirs generally point out the efforts Sibe villagers made to prevent fleeing GMD officials from escaping through their district. ${ }^{77}$ Sumutong's written account states that the GMD officials sent to govern Cabcal held out in the First Niru for some time and that Eršan even sheltered a high-ranking Nationalist Party official in his home in the Seventh Niru. These GMD officials were eventually permitted to flee to Huiyuan 惠遠 (where they eventually all died). ${ }^{78}$ Eršan had in fact previously served the GMD government as the head of the Sibe district of Ningxi (Cabcal) Countynearly the exact same position he was to hold under the new regime. From these small incidents it would appear that some segments of the Sibe community may have had mixed or even positive feelings towards the GMD. It was also far from clear that the ETR forces would prevail in their battles with the GMD garrison in Ili. In December of 1944, several Nationalist attempts to relieve their forces had nearly succeeded.

It also may be that the initial ideology of the ETR held little appeal to the nonTurkic, non-Muslim Sibe. Early proclamations issued by the new regime in Gulja de-

74. Forbes, Warlords and Muslims in Chinese Central Asia, 183; Ujalan, Sibe moringga liyan coohai ejebun, 12-13. This military force is referred to in Uyghur as the "milliy armiye" and in Sibe as the "uksurai cooha."

75. Wu Haomin, "Šive atliq iskadroni heqqide eslime," 50-51. An ethnic Sibe intelligence officer, Xi Jijing, seems to have been attached to the general staff for some time prior to January 1945: Wu Haomin, "Šive atliq iskadroni heqqide eslime," 65.

76. Ujalan, Sibe moringga liyan coohai ejebun, 23.

77. Ujalan, Sibe moringga liyan coohai ejebun, 9.

78. Šumutong 舒慕同, “Guanyu Sanqu geming shiqi Sumuer xian de pianduan huiyi” 关于三区革命时期苏木尔县的片 断回忆 (An incomplete recollection of Sumul County during the Three Districts Revolution), Yili wenshi ziliao 6 (1990): 44; interview, August 15, 2007. 
clared their intention to establish a Muslim state under sharia law. ${ }^{79}$ The wide-scale killings of non-Muslims and non-Turkic people also disturbed the Sibe I interviewed. Several of the sources reveal that within the ETR movement itself there were significant disagreements over the direction of the revolution. Forbes argues that following the successful conclusion of military campaigns against GMD installations in Ili, ETR leaders began to tone down the ethnic and religious rhetoric and that a more "progressive party," interested in promoting USSR-style socialism and a more inclusive ideology vis-à-vis the other ethnic groups in the region, rose to prominence. ${ }^{80}$ Šumutong's recollections support Forbes's assertion. Šumutong recounted that early during the revolution he went to visit his friend Abbasoff, a member of the ETR's ruling inner circle, and asked him what he made of the ethnic bloodshed. According to Šumutong, Abbasof replied, "Don't look at the current situation, just wait until things develop further." On the basis of this conversation, Abbasof convinced Šumutong to join the movement. ${ }^{81}$ The growing prominence of these figures is evidenced by the second article of the Gulja Declaration that states the following goal: "The creation of a 'Democratic Base' founded on the equality of all nationalities inhabiting the territory of the ETR." ${ }^{2}$

Ujalan Liyanšeng also notes this shift. He divides ETR leadership into three types, progressive, capitalist, and feudal, and suggests that Exmet Jan Qasim (of the progressive camp) had succeeded in pushing the ETR ideology to the left. ${ }^{83}$ He states that in response to the decision to create a Sibe unit, "The 11,000 inhabitants of Cabcal were overjoyed at this news and supported dispatching troops because the revolution had equalized the power among all ethnic groups." ${ }^{84}$ It is precisely this call for justice on ethnic grounds - a redress of grievances vis-à-vis the Han — that is central to the way both Ujalan and Wu Haomin remember the event, even though neither author explicitly identifies the Han. Wu Haomin writes that, "The Sibe greeted the ethnic revolutionary movement with great sympathy." 85

Šumutong, however, offers a significantly different account of the formation of the company. Over the course of two interviews he described how, as an intelligence officer and translator for the new ETR army, he accompanied Polinov to Cabcal to meet

79. Benson, Ili Rebellion, 44-45.

80. Forbes, Warlords and Muslims in Chinese Central Asia, 182. In the winter and spring of 1945, the ETR initiated a number of social projects such as spring planting and educational initiatives that, according to later accounts, increased popular support for the regime. See Xibozu jianshi, 72; Xibozu baikequanshu, 225; and Forbes, Warlords and Muslims in Chinese Central Asia, 184.

81. Šumutong, interview, August 5, 2007.

82. Forbes, Warlords and Muslims in Chinese Central Asia, 183. Owen Lattimore notes that the creation of a "National Council" in the ETR that spanned ethnic groups encouraged support from the Sibe. He writes that the Sibe, "earned great praise for 'distinguishing themselves in carrying out tasks assigned them by the Gulja regime, such as delivering grain and clover." Lattimore, Pivot of Asia (New York: AMS Press, 1975), pp. 87, 148-49.

83. Ujalan, Sibe moringga liyan coohai ejebun, 18-19.

84. Ujalan, Sibe moringga liyan coohai ejebun, 23-24.

85. Wu Haomin, "Šive atliq iskadroni heqqide eslime," 50; emphasis added. 
with leaders from the Sibe niru. According to his account, Cangdešan and Eršan were extremely reluctant to commit troops: "So Polinov explained to Cangdešan that all the other ethnic groups had dispatched troops and asked, 'How would it look if you don't participate?' The Sibe were willing because otherwise all the other ethnic groups would look down us." ${ }^{86}$ Šmutong repeatedly stressed that the Sibe's participation in the ETR army was a question of the group's honor and status vis-à-vis the other ethnic groups. Polinov's rhetoric also played to the tradition of military service that stood at the core of Sibe identity. Other Sibe who had witnessed the formation of the cavalry company also repeatedly stressed that the centrality of military service within Sibe culture contributed to their decision to comply with the ETR's levy. One man recalled, "In those days the niru really resembled military camps. People just expected to serve as soldiers." ${ }^{\prime 7}$

Moreover, Šumutong explained that Polinov's question to Cangdešan was also a subtle political threat: failure to participate meant the forfeit any right they might have to equal treatment under the new government. ${ }^{88}$ It would also have implications for the distribution of power in Cabcal County as well where, numerically speaking, Uyghurs and Kazaks outnumbered the Sibe, and therefore the local administration could be reasonably reorganized on terms less favorable to the Sibe. Šumutong's oral account suggests there was a degree of coercion on the part of the ETR government, but that in the end the Sibe officials made a decision to commit to the movement based on the desire to protect and maintain the political and economic benefits that had accrued to the Sibe niru since the GMD had departed. Šumutong also stated that the ETR had first requested a battalion of Sibe troops, but that in the end the eight niru could only muster a company. ${ }^{89}$

General Polinov himself came among the niru to recruit soldiers. Wu Haomin writes that he supervised the recruitment drive with a great deal of care, particularly the selection of the officers. ${ }^{90}$ According to Šumutong and Funggantai, service was compulsory: every family with two sons of fighting age had to commit one son to the force. Horses and other supplies were requisitioned from wealthy families. ${ }^{91}$ Compulsory service, however, does not necessarily mean that the Sibe were drafted against their will. The sources all agree that most Sibe soldiers were highly motivated to enlist. Ujalan and Wu Haomin do not mention that military service was compulsory. Ujalan writes that the recruits voluntarily enlisted and did so to express their gratitude to the new government

86. Šumutong, interview, August 5, 2007.

87. Anonymous interview, August 4, 2007.

88. Šumutong, interview, August 15, 2007.

89. Šumutong, interview, August 15, 2007.

90. Wu Haomin, "Šive atliq iskadroni heqqide eslime," 51.

91. Šumutong, "Guanyu Sanqu geming shiqi Sumuer xian de pianduan huiyi," 47; Funggantai, "Guanyu Sanqu geming Xibo qibing lian de pianduan huiyi," 95. 
for bringing relief from oppression. ${ }^{92}$ The Sibe went to war, he says, "to protect Ili and uphold the fruits of the revolution." ${ }^{93}$

The use of the term "revolution," however, is problematic in these written accounts because the word itself did not exist in Sibe until 1946. Šumutong's friend Guan Qinglian coined the phrase for use in the new Sibe-language newspaper published in Gulja. ${ }^{94}$ Prior to this, Sibe were using a variety of loan words from Chinese, Eastern Turki (Uyghur), and Russian and therefore would have at best understood this term in the context of how the word had been used in its original language. The concept first came into common use in Sibe language via the Chinese term geming 革命 in the years surrounding the Xinhai Revolution. In its earliest usage "geming" in Cabcal was alternately a cognate for "rebellion" (facubün) or the violent overthrow of the Qing in the name of Han-dominated rule. By the late 1930s, a number of Sibe had been exposed to the Russian revolution during the course of their educations in the USSR, and an even smaller number (perhaps two or three Sibe intellectuals) had had some contact with members of the Chinese Communist Party. Many Sibe had also come in contact with Russian and Kazak refugees who had fled from the USSR. Thus, although in 1944 the idea of "revolution" as a dramatic political reorientation of society on class lines had probably begun to circulate among Sibe elites, revolution still probably looked more like a kind of violence against one ethnic group by another. Regardless, it appears that the Sibe saw the events of 1944 first in the context of their own local history of ethnic and religious unrest—as "Muslim Chaos"—and, as people began to refer to the new government as a "revolution" (using primarily the Russian or Turkic words) in the winter of 1944-1945, it continued to be understood by most as a revolutionary realignment of power along ethnic lines. ${ }^{95}$

Throughout the ETR period, the Sibe referred to the new government not as the "Three Districts Government" but rather as Turkestan, and the ETR army as the Turkestan coohas, "the Turkestan troops." ${ }^{\prime 9}$ According to Šumutong, during the first winter and spring of the ETR, "There were no red flags. No one spoke of socialism . . . . People opposed the GMD and they opposed Great Han Chauvinism." ${ }^{97}$ The idea that they were receiving direction from the Chinese Communist Party struck Šumutong as absurd. "There was no communication with the CCP. Actually, we thought all the communists were the same and didn't know the Chinese were separate from the Soviets." ${ }^{98}$

92. Ujalan, Sibe moringga liyan coohai ejebun, 23-24.

93. Ujalan, Sibe moringga liyan coohai ejebun, 119

94. Šumutong, interview, August 15, 2007. The term irgejengge, "democratic," also entered the Sibe vocabulary at this time. 95. Anonymous interview, August 6, 2007.

96. Šumutong, interview, August 15, 2007.

97. Šumutong, interview, August 5, 2007.

98. Šumutong, interview, August 5, 2007. 
As the campaign unfolded though, motives and ideology would evolve as the soldiers were exposed to new situations and the violence of the battlefield.

The Sibe Independent Cavalry Company was first mustered in the Seventh Niru. Its full complement of 150 troops and officers were quartered in the homes of local families. An ethnic Sibe, Nar Bayantu, was called on to command the company. Nar Bayantu had been drafted at the age of nineteen into the military forces of Yang Zengxin and had risen to the level of major in the military forces stationed in Bortala. Since 1937, however, he had been teaching at the primary school in the First Niru. ${ }^{99}$ Fuča Šingsen was the second-in-command. ${ }^{100}$ Both Sibe memoirists highly dramatize the character of Nar Bayantu, making him the central figure in both accounts. Standing several inches taller than the other soldiers, he strode about in red boots, and is portrayed as having strong personal connections to the troops. The appearance of both of these officers, gushes Ujalan, was "exceedingly awe-inspiring and resplendent." 101 The third officer of significance to both memoirists was the company's Russian language translator, Syšan.

The company was subdivided into four platoons, which were further divided into twelve squads. The company headquarters also included a quartermaster (Funggantai), a cook, medical orderlies, logistic supply soldiers, and one communications specialist. Each platoon was assigned one heavy machine gun (Funggantai, reports, however that even by the time of their first major engagement with the enemy at Yongjihu, the company had only one working machine gun). ${ }^{102}$ The majority of the soldiers were young, between the ages of eighteen and twenty; in Ujalan's words, they were "people of the fields," unfamiliar with weapons and maneuvering on horseback. ${ }^{103}$ For the next four months, the unit engaged in intensive drill and training, while General Polinov traveled across the river from time to time to supervise the training. Wu Haomin writes that, "When the unit was first established, there was no one single set of rules and regulations. Sibe commanders drew on their own previous military experience and worked hard to instill discipline among the troops." 104 Troops were taught how to shoot from the saddle, how to dodge enemy projectiles, how to maneuver across the landscape and over various obstacles. ${ }^{105}$

99. Xinjiang Xibozu renwulu, 48.

100. Fuca Šingsen, according to Wu Haomin, was skilled at reconnaissance, guarding operations, and finding water: Wu Haomin, "Šive atliq iskadroni heqqide eslime," 52. According to Funggantai, Fuca had served as an artillery officer in the army of Zhang Peiyuan 張培元 that assisted first Jin Shuren then Sheng Shicai in putting down the Muslim rebellions in Hami and Turpan. Zhang later turned on Sheng and tried to establish his own domain in Ili. Sheng forces defeated Zhang's army in 1934, returning Ili to Sheng's control. It appears then that Fuca had actually already fought once against Sheng. Funggantai, "Guanyu Sanqu geming Xibo qibing lian de pianduan huiyi," 95.

101. Ujalan, Sibe moringga liyan coohai ejebun, 31.

102. Funggantai, "Guanyu Sanqu geming Xibo qibing lian de pianduan huiyi,” 99.

103. Ujalan, Sibe moringga liyan coohai ejebun, 47; Wu Haomin, "Šive atliq iskadroni heqqide eslime," 85.

104. Wu Haomin, "Šive atliq iskadroni heqqide eslime," 80.

105. Ujalan, Sibe moringga liyan coohai ejebun, 63-64. 


\section{Crossing the River to Revolution}

On April 8, 1945, the National Army of the ETR was officially founded, and the ETR government held a military review in streets of Gulja. ${ }^{106}$ Shortly afterwards, the Sibe Independent Cavalry Company was ordered to cross over the Ili River from Cabcal and join the main body of the Ili National Army. Upon arriving in Gulja, the general staff of the ETR military forces transferred the Sibe unit into the Independent Cavalry Battalion of the Second Cavalry Regiment (the appellation "independent" was dropped from the name of the Sibe unit). This new battalion consisted of the Sibe First Company, the Russian Second Company, and the Hui Third Company. ${ }^{107}$ A Soviet military advisor, Major Barsov, ${ }^{108}$ and a political affairs supervisor, Captain Emet Axun, were assigned to the battalion, as was an ethnic Russian nurse, Tanya, and a Uyghur doctor, Aisiyambu. ${ }^{109}$

After their arrival, coordinated military training began with other units. It was not until this training had been completed (late April) that the soldiers of the Sibe company were fully outfitted with weapons and ammunition. ${ }^{110}$ The Uyghur village of Piyanjima hosted the Sibe during the course of their training in Gulja. ${ }^{111}$ Provisioning the troops on the road, however, was extremely challenging, as for much of the campaign the Sibe camped in the open country. ${ }^{12}$ The troops' standard ration consisted of 800 grams (one pound twelve ounces) of bread a day. Once a week, they were issued 500 grams (a little over one pound) of "meat on the bone." With these provisions, Wu wrote, "No one was ever full!" 113 They were provided with mattresses and thin blankets, and soldiers usually supplemented these using their saddle blankets and saddle pads. Each soldier was issued a cotton uniform shirt and pants and a large collarless cloak. ${ }^{114}$

In the spring of 1945 , the ETR government formulated a three-front strategy with

106. Wu Haomin, "Šive atliq iskadroni heqqide eslime," 52.

107. Wu Haomin, "Šive atliq iskadroni heqqide eslime," 52. Ujalan's description of this new formation is slightly different. He does not include the Hui unit within the Independent Cavalry Battalion. Rather, the Hui fought as a separate unit at regiment strength and frequently fought alongside the Mongol Cavalry Regiment: Ujalan, Sibe moringga liyan coohai ejebun, 46. Wu identifies the battalion commander as Polšin; Ujalan identifies Leskin as the commander of the Second Cavalry Regiment.

108. Funggantai writes that Barisov was the battalion commander, while Polšin was an officer of the General Staff. Funggantai also agrees with Wu that a Hui company was part of the battalion. Funggantai, "Guanyu Sanqu geming Xibo qibing lian de pianduan huiyi," 98, 101.

109. From the name, I assume that Emet Axun was Uyghur. Ethnically Russian officers played a major role in the affairs of the Sibe Cavalry Company, yet these were naturalized residents of the Ili Valley. Wu Haomin explicitly identifies those Russians who were Soviet advisors. These two memoirs counter Forbes's claim that Chinese Muslims did not fight for the ETR. The name that appears as "Aisiyambu" in Sibe text may be the Uyghur name "Asa Jan."

110. Wu Haomin, "Šive atliq iskadroni heqqide eslime," 54.

111. Ujalan, Sibe moringga liyan coohai ejebun, 78.

112. Wu Haomin, "Šive atliq iskadroni heqqide eslime," 87.

113. Wu Haomin, "Šive atliq iskadroni heqqide eslime," 85.

114. Wu Haomin, "Šive atliq iskadroni heqqide eslime," 88. Before leaving Cabcal, the Sibe community had also provided the troops with several cartloads of other material, including sheepskin coats. 
northern, central, and southern lines of attack. In March, the northern wing of the INA marched towards the town of Targhabatay (also known as Tacheng or Chüchek). The southern wing crossed over the Tianshan and started raiding GMD garrisons in the oasis cities of the Tarim Basin. The Sibe unit was attached to the central front, and the strategic target of this campaign was the series of GMD garrison towns along the main road between Gulja and Ürümchi. The GMD had committed fresh and experienced troops from the Chinese interior to these towns (including a large contingent of $\mathrm{Ma}$ Bufang's馬步芳 Sino-Muslim Fifth Cavalry Army, dispatched from Qinghai) and had spent the winter and spring shoring up their defenses. ${ }^{115}$ The GMD forces were located in the walled county towns of Jinghe and Xihu 西湖 (present-day Wusu). During the course of this campaign, the highly mobile INA pinned down and isolated the Chinese military units in these towns, capturing them one by one in heavy fighting over the summer of $1945 .{ }^{116}$

\section{Politics of a Revolutionary Military Force}

The Sibe soldiers fought in their first military engagement on June 29, 1945, when they helped blunt a GMD attempt to retake the hamlet of Yongjihu, south of Jinghe. This action was quite costly for the Sibe cavalry company. Seven soldiers were killed, seven were taken prisoner, the company's nurse, Tanya, was wounded, and over forty horses had been killed during the bombardment preceding the assault. ${ }^{117}$

Sibe memoirists agree that it was at this time that officers from the ETR general staff and subordinate political affairs officers began to educate the company's soldiers about the greater implications of their local fight against the GMD. According to Wu Haomin, Ibray Hakimov (of the General Staff) held three classes for the company's troops in order to explain the war in Xinjiang and its place in the global war against fascism. Wu does not mention any education about the war against Japan or between the GMD and the CCP. Wu Haomin states that, "Because the classes were extremely detailed, deep, meaningful, popular, and comprehensible, everyone in the company, from regular soldiers to officers, obtained a deep education, a much clearer understanding of the goals of the army, and a belief in the righteousness and eventual victory of the ethnic

115. Ujalan, Sibe moringga liyan coohai ejebun, 117; Forbes, Warlords and Muslims in Chinese Central Asia, 186. Šumutong disputes this and believes that Ma Bufang's cavalry, although dispatched to Xinjiang, was stationed around Ürümchi and north of the Bogda range of the Tianshan mountains around Jimsar, Mori, and Bark ǔ l. Interview, August 15, 2007.

116. List of specific engagements, from Wu Haomin, "Šive atliq iskadroni heqqide eslime": Yongjihu; Bajiahu; Čing/ Jinghe county town; Qumbulaq; Gortu; Totu; Čigišur; Kona Šihu/ Lao Xihu (Wusu); and Manas.

117. Wu Haomin, "Šive atliq iskadroni heqqide eslime," 63. According to Ujalan, these prisoners were taken to Ürümchi. The Sibe-Solon Cultural Office in Ürümchi made inquiries into the matter and in October of 1946 secured their release. Ujalan, Sibe moringga liyan coohai ejebun, 185; Funggantai, "Guanyu Sanqu geming Xibo qibing lian de pianduan huiyi," 101. 
revolution." ${ }^{118}$ Although this sentence is belabored with adjectives, it is revealing to note Wu's choice of language. He describes the revolution not with the Uyghur word xalq, which means "people" and is the standard Uyghur adjective applied to the communist revolution in the PRC. Instead he uses milliy ("ethnic"), an adjective with narrow connotations that excludes the Han.

Among the goals of propagandists within the ETR military, foremost was a desire to instill morale and a sense of camaraderie across their multi-ethnic force. In a broader sense, however, the rhetoric of a socialist revolution idealized the soldier as having significant tasks to accomplish beyond mere soldiering and beyond the protection of his own community's parochial interests. At this point, nearly a year after the initial outbreak of violence in Ili, accounts of socialist propaganda filtering through the troops became more credible. All the sources testify to a significant presence within the INA of local officers who had been trained in the USSR and of Soviet military advisors. In preparation for the large-scale assault on Jinghe, significant quantities of Soviet arms (rifles, machine guns, and mortars) were distributed to the troops, and even a number of Red Army units had been directly attached to the ETR army. ${ }^{119}$ The impact these new lessons must have had at the time, though, is certainly brought home by the fact that both memoirists, writing forty years later, still frame their narratives in terms of World War Two's resisting fascism rhetoric and not in the standard PRC "war of resistance against Japan" or "war of liberation" (civil war) rhetoric.

A political affairs officer, Emet Axun, as mentioned earlier, had been attached to the Second Cavalry Regiment when the unit was originally organized in Gulja, and Wu Haomin credits him with doing "extremely good work." 120 In the early summer, Emet Axun identified political leaders and workers in each battalion and company, creating an overall propaganda troupe with representatives from different units of the regiment. A Hui officer, Ramazan, and a Russian officer, Baxirov, were in charge of propaganda for the cavalry battalion. As its first task, the new propaganda troupe worked to publicize the heroes of the Sibe Company, as well as the daily lives of the Hui and Russian soldiers.

Wu Haomin relates that he was put in charge of preparing materials about the Sibe Company and translating them into Uyghur. The propaganda troupe was organized into two subgroups, one for "oral propaganda" and one for "visual propaganda and exhibitions." Ramazan was in charge of the visual propaganda. He organized an exhibition of paintings of heroes from the cavalry battalion, among whom were several Sibe troopers. These paintings were then affixed to red cloth banners and taken around to the infantry battalions. Uyghur soldiers with particularly good voices were selected to

118. Wu Haomin, “Šive atliq iskadroni heqqide eslime," 66; emphasis added.

119. Funggantai, "Guanyu Sanqu geming Xibo qibing lian de pianduan huiyi," 103-4; Šumutong, interview, August 5, 2007.

120. Wu Haomin, "Šive atliq iskadroni heqqide eslime," 68. 
accompany the images and do "voice-overs" recounting the heroic tales. ${ }^{121}$ Wu Haomin claims that the fame of the Sibe unit spread throughout the army. Although he may be exaggerating, one cannot help but agree that this small contingent, situated as it was among the estimated 30,000 INA troops, was something of a novelty.

\section{The Battle for Jinghe}

In the aftermath of the battle for the defense of Yongihu, the general staff of the ETR army shifted the cavalry battalion to which the Sibe company belonged from the Second Cavalry Regiment to the Gulja Second Regiment. This new regiment consisted of one cavalry battalion (which included the Sibe company) and two Uyghur infantry battalions. This regiment also contained one artillery company, one reconnaissance company, and one medical detail. The Sibe Company was re-outfitted with military equipment at this time. ${ }^{122}$ The vice-commander of the Sibe cavalry company, Fuca Šingsen, was wounded in the hand during the Bajiahu八家戶 battle and was temporary replaced with an ethnic Kyrgyz officer, Motuzan. ${ }^{123}$

In the late summer of 1945 , the ETR army went on the offensive, committing approximately 4,000 troops to the battle for Jinghe. The battle began on September 3d with simultaneous attacks on Yongjihu and Bajiahu, the outer defenses of Jinghe. The mission of the Sibe company was to cross over the enemy lines near Bajiahu, eliminate the GMD's pickets, and then capture an abandoned village at the far end of the enemy's line of defense. Next, the Sibe were to circle behind the enemy lines and block the line of retreat from Bajiahu to Jinghe. ${ }^{124}$ This day's work proved to be extremely costly for the Sibe. ${ }^{125}$

The attack opened up with an aerial bombardment by planes captured from the GMD airfield in Gulja, and the Sibe forces staked out their positions with white flags to avoid becoming victims of friendly fire. Šumutong asserts that the planes were from the USSR air force and that the Soviets also directly contributed artillery units to the siege. ${ }^{126}$ The Sibe proceeded on horseback into enemy territory without incident, but when they arrived at the abandoned village, they found that the GMD had constructed a bunker with concealed firing positions all around it. ${ }^{127}$ It took three separate sorties

121. Wu Haomin, "Šive atliq iskadroni heqqide eslime," 69.

122. Wu Haomin, "Šive atliq iskadroni heqqide eslime," 67. The Gulja Second Regiment was commanded at this time by Captain Pidayov; the Chief of Regiment staff was Kiriminov; the Soviet Advisor was Major Barsov (explicitly recognized as Soviet); the political section head was Emet Axun; and a religious leader "Axun" was also assigned to the regiment.

123. Wu Haomin, "Šive atliq iskadroni heqqide eslime," 70.

124. Ujalan, Sibe moringga liyan coohai ejebun, 128-29.

125. Wu Haomin, "Šive atliq iskadroni heqqide eslime," 71.

126. Šumutong, interview, August 4, 2007.

127. Wu Haomin, "Šive atliq iskadroni heqqide eslime," 74. 
by Sibe troops to finally reduce the bunker, and each attempt led to considerable loss of life on the Sibe side. ${ }^{128}$ In the chaos that followed the capture of Jinghe, another thirteen Sibe soldiers were taken captive by remnants of the GMD military forces and subsequently executed. According to Ujalan, the sight of their tortured bodies so shattered the soldiers of the Sibe company that soldiers from other units had to collect and bury the dead. ${ }^{129}$

\section{Ethnic Relations in the INA}

The Sibe cavalry company participated in the long pursuit of the GMD as it fled east. In October of 1945, the front lines of the war stabilized along the banks of the Manas River, and the Sibe forces spent the long winter in Ulatsun, near the present-day city of Shehezi 石河子. Wu Haomin recalls that it was only at this point in the campaign that Emet Axun held a political meeting to inform the troops that World War Two had ended and that victory over fascism had been realized. ${ }^{130}$ Under pressure from the Soviet Union, the ETR leadership backed away from continued offensive actions and entered into negotiations with the GMD in October. ${ }^{131}$ The battle for Jinghe had reduced the Sibe Cavalry Company to two platoons: to return the company to full complement, two platoons of Uyghur cavalry were placed under the control of Nar Bayantu in November. ${ }^{132}$

Each successive restructuring the of the ETR forces not only brought the Sibe Company into more frequent contact with soldiers from different ethnic groups but also integrated them more closely into multi-ethnic units. Throughout the war, the basic unit of the INA, the platoon, remained segregated by ethnicity. Yet as the campaign progressed, the general staff of the ETR army repeatedly restructured their forces in response to casualties and the necessities of the battlefield. As a result, soldiers from different ethnic groups were integrated first at the regiment and battalion levels, then later at the company level. As we have seen, during the initial stage of the campaign (from the date of their arrival in Gulja in April 1945 through their first battle near Bajiahu on June 29), the Sibe company served in a battalion that also housed a Russian company and possibly a Hui company as well. In preparation for the assault on Jinghe, the Sibe unit was again reshuffled, this time into a Uyghur infantry regiment in order to provide

128. The new Kyrgyz officer, Motuzan, and five Sibe soldiers died in the attack. Ujalan, Sibe moringga liyan coohai ejebun, 129.

129. The battle for Jinghe, roughly speaking, involved 4,000 INA troops and 7,000 GMD troops. The INA lost nearly 1,000 men in the attack and took 3,000 GMD troops prisoner. Wu Haomin, "Šive atliq iskadroni heqqide eslime," 79; HTDR, 80 .

130. Wu Haomin, "Šive atliq iskadroni heqqide eslime," 79.

131. Benson, Ili Rebellion, 55.

132. Ujalan, Sibe moringga liyan coohai ejebun, 171; Wu Haomin, "Šive atliq iskadroni heqqide eslime," 80-81. 
flank support. Now, in the early winter, the Sibe company itself had become a multiethnic unit.

Within the ETR forces, it was not rare for officers to command units that were of a different ethnicity. As we have seen, the Sibe unit generally fought in battalions officered by either Russians from Ili or Soviet officers of diverse backgrounds, and command of the company was at one point split between Nar Bayantu and the unfortunate Kyrgyz officer. Within the two regiments in which the Sibe served, Russian appears to have been the primary language of communication among the officer corps. This is not surprising considering that most of the staff of the INA had a shared history of education and activism in the Soviet SSRs. For officers of the INA especially, the experience of the campaign helped to build up a network of supra-ethnic and supra-regional connections that would serve them well in their future civilian and military careers. ${ }^{133}$

The addition of Uyghur platoons does not appear to have been smooth. The officers of the Sibe unit could not speak Uyghur and thus the Uyghur soldiers had to be drilled in a mixture of Russian and Sibe. Wu Haomin states that the new troops were treated amicably and welcomed. Yet both his and Ujalan's warmest memories (and a good deal of ink) are reserved for their Dagur and Sibe comrades from Targhabatay, who were added to the company in May of 1946. For both authors, "the cultural life of the company was really invigorated after the Dagurs and Sibe from Targhabatay joined our unit." 134 This new platoon included several musicians and singers who were versed in a variety of dances and songs from both sides of the USSR-Xinjiang border. The arrival of these troops was also significant because it established ties between Sibe groups from different parts of Xinjiang. For reasons left unstated by both authors, the Uyghur platoons were transferred to another unit after two months, yet it seems clear that the Uyghurs were not as easy a fit as the unit of Sibe and Dagurs from northern Xinjiang. ${ }^{135}$

Ethnicity clearly mattered within the ETR army and inter-ethnic relations were not always smooth. Wu Haomin identifies several points of contention in his narrative. The first of these was squabbling over rations between different units. During the long, static phase of the war (from the winter of 1945-1946 through the following spring), troops began to complain that food supplies were not equally distributed, thievery broke out between units, and ethnic tensions flared. Wu credits Nar Bayantu with stepping in a creating a more transparent and equitable food distribution system. ${ }^{136} \mathrm{Wu}$ also writes that, "Although it was extremely rare, some soldiers discriminated against the soldiers and officers of other units, and when they met soldiers and officers of other

133. Wu Haomin, “Šive atliq iskadroni heqqide eslime," 81; Šumutong, interview, August 4, 2007.

134. Wu Haomin, "Šive atliq iskadroni heqqide eslime," 89.

135. Ujalan, Sibe moringga liyan coohai ejebun, 172.

136. Wu Haomin, "Šive atliq iskadroni heqqide eslime," 85-86. 
ethnic groups they would not greet them or salute." ${ }^{137}$ Upon hearing complaints from other officers, Nar Bayantu reportedly admonished his troops thus:

Within our ethnic liberation front, regardless of what ethnic group you are from, all of us are equal. Therefore, each person should receive the same treatment. All of us have come together to destroy a common enemy. We must respect each other, trust one another and strengthen our mutual friendship. We must act in unity as if we were one. If we act thus, our military unity will not break. ${ }^{138}$

The choice of words in this passage is significant for reasons beyond being a stirring example of Nar Bayantu's enlightened leadership. Wu's use of the expression "ethnic liberation front" (milliy azadliq front in Uyghur), which more literally could be translated as "front for the liberation of ethnic groups," can only be understood as liberation vis-à-vis the Han Chinese. Such an expression is very much out of line with the PRC's sanctioned language for describing the Three Districts Revolution. Much like previous passages, Wu's impolitic choice of words reveals that, at least as he remembers it, the campaign was ethnically charged, one understood more in terms of ethnicity than class.

\section{Return to Cabcal}

On January 3, 1946, delegates from the ETR and the GMD signed an initial peace accord. A second agreement was signed in June and broadly established the principles by which a new representative government would be selected for Xinjiang, and in July, representatives from the Ili government arrived in Ürümchi to take up their posts in the new united government. ${ }^{139}$ With tensions temporarily easing across the province, the Sibe troops were given permission to return to Cabcal in July. Ujalan recalls that only sixty soldiers returned from the war in the final group (the wounded and ill had returned separately earlier). Upon arrival at the Airambek military base in Gulja, the ETR government paid the soldiers and then presented them with official discharge certificates. ${ }^{140}$

Under the terms of the two peace agreements, the ETR government organized elections across the three districts. The election committee in Cabcal consisted of two Sibe, one Uyghur, and two Kazaks. On November 29, 1946, a large meeting was held to

137. Wu Haomin, "Šive atliq iskadroni heqqide eslime," 86.

138. Wu Haomin, "Šive atliq iskadroni heqqide eslime," 86.

139. Benson, Ili Rebellion, 58-63; Ujalan, Sibe moringga liyan coohai ejebun, 172.

140. There are some discrepancies in accounts of their discharge. Ujalan, Sibe moringga liyan coohai ejebun, 184-87; Funggantai, "Guanyu Sanqu geming Xibo qibing lian de pianduan huiyi," 107. 
select county officials and representatives to the new provincial government. Among the men selected, men who had returned from service in the INA figured prominently. ${ }^{141}$ According to Šumutong, on the eve of the election, ETR intelligence services uncovered communications between Cangdešan and a Sibe from Tarbaghatay whom the GMD had dispatched as an official "observer" to the Cabcal County elections. ETR intelligence also believed that Cangdešan had already garnered the support of enough delegates to be re-elected to office. Thus fearing that a potential GMD-supported candidate was about to be elected, the ETR general staff dispatched Šumutong to Cabcal to contest the elections. Šumutong recalls being shocked, "I was only twenty-seven. It was impossible that I could be elected magistrate!" His supervisor told him not to worry and that it would be taken care of. Sure enough, according to Sumutong, ETR agents and other Sibe who had returned from service with the ETR turned out enough delegates that he was elected to replace Cangdešan. ${ }^{142}$ Nar Bayantu was chosen to become the vice director of the police bureau of Sumul County. The seating of this new administration and the ousting of Cangdešan and Eršan also formally dissolved the banner positions of banner and niru commandant for the second time.

Over the next four years, it was leaders like these who, often in cooperation with the ETR government in Gulja, initiated a broad range of social and economic measures in Cabcal that are still positively remembered by villagers today. Šumutong, with the support of the ETR education minister Saiffudin Aziz, established the first middle school in Cabcal in the Sixth Niru. ${ }^{143}$ In 1947, students from this school and youth from across Cabcal started a countywide prohibition campaign and destroyed many of the local distilleries. ${ }^{144}$ In important ways, active Sibe participation in the ETR's military campaigns enfranchised this group within the broader ETR movement. By the ETR's own standards, the Sibe cavalry company was a highly decorated unit, and this gave the Sibe political standing in the Three Districts government.

Many of the Sibe soldiers who returned from the front in 1946 shortly thereafter returned to work in the ETR military or in other official positions across the ETR government. Sibe translated their language skills and Soviet educations (many of which had been built up during the course of the campaign) into positions in the ETR public security bureau and the bureau of construction and irrigation, and one Sibe, Guan Ronglai, also served on the overall ETR military affairs committee throughout the ETR period. The Sibe also used their newfound freedom under the ETR to establish connec-

141. Xibozu baikequanshu, 235.

142. Šumutong, "Guanyu Sanqu geming shiqi Sumuer xian de pianduan huiyi," 48; interviews, August 5 and 15, 2007.

143. Šumutong, interview, August 5, 2007.

144. Šumutong, interview August 5, 2007; Tong Qichun 同奇春, “Sanqu geming shiqi Xibozu de jinjiu yundong”三 区革命时期锡伯族的禁酒运动 (The prohibition movement among the Sibe during the Three Districts Revolution), Chabucha'er Xibozu zizhi xian wenshi ziliao 察布查尔锡伯族自治县文史资料 I (1996): 85-90. According to Sumutong, the resulting lawsuits wound their way completely through the ETR courts and were finally settled by the Soviet consul. 
tions with other former banner peoples across the Three Districts and to establish new Sibe-Solon-Manchu cultural institutions and the first Sibe-language newspaper, the Ice jugün serkin, "New Road Newspaper." 145

When operatives from the Chinese Communist Party began to trickle in to the Ili Valley in January of 1950, the success and prestige of ETR officials like Nar Bayantu presented enormous obstacles to the Party's efforts to insert its own officials and implement the revolutionary policies of People's Republic of China. According to Šumutong, when the first PLA units arrived in Cabcal from Huiyuan, they were able to do little more than change the names of the various ETR-era institutions and left all the ETR cadres in place. ${ }^{146}$ Moreover, as a result of Mao's decision to include the ETR within China's "great democratic revolutionary movement," it was difficult for the CCP to remove local ETR officials or even claim that the PLA had "liberated" the region. Both Nar Bayantu and Šumutong, for instance, went on to have long and prestigious careers in the PRC. ${ }^{147}$ From the description of "revolution" as it appears in the memoirs of Ujalan Liyanšeng and Wu Haomin, the Sibe in Cabcal had already redressed their community's primary grievances - they had eliminated the increasingly dangerous and oppressive rule of Han Chinese officials and established a limited degree of self-rule in the eight Sibe niru. In 1949, Sibe did not refer to the arrival of PLA troops as "liberation." In fact, the term "liberation," or sulambusün, did not enter the Sibe language until the mid-1950s and since then it has referred only to November of 1944 and the establishment of the Wergi Turkestan gongheg'u-the "Eastern Turkestan Republic." 148

\section{Conclusion}

Recent academic work on the Eastern Turkestan movement, particularly that published in mainland China, has largely been consumed with addressing the question of Soviet involvement. During the course of researching this paper, I have come across a good deal of evidence for the position that the USSR was deeply involved in the conflict and that its involvement contributed to the overall success of the military campaign. I also

145. Xibozu renwulu, 38, 40-42, 53, 54. Salacun, Šumutong's father, was the main editor of this newspaper. The press had a circulation of about two hundred and an edition ran every two to three days. The international news content was drawn from the USSR news service TAS.

146. Šumutong, interviews, August 5 and 15, 2007.

147. Post-1949, Nar Bayantu helped found the Peasants' Association in the county and participated in the "reduce rent, reduce interest, oppose local despots" movement. In 1957, he became county vice-magistrate and was a representative in the Peoples' Political Consultative Congress. Šumutong was appointed to the position of vice-director of the provinciallevel Xinjiang department of Public Security in the winter of 1949-1950 and later on also served as a standing member of Xinjiang's party committee. Guan Ronglai, who served on the ETR military committee, did not fare as well, and from 1957's anti-rightist campaign on, spent most of his time in jail until he was exonerated in the late 1970s. Xinjiang Xibozu renwulu, 48, 53, 54 .

148. Šumutong, interview, August 5, 2007; anonymous interview, August 6, 2007. 
came across tidbits of information about the extent to which the Soviets tried to hide their involvement. Funggantai, for instance, describes how, while stationed at Anjihai 安集海 in the early winter of 1945-1946, the regimental authorities collected all the weapons with the marks of Russian manufacturers and replaced them with weapons taken from captured GMD armories. ${ }^{149}$ Yet the debate over Soviet involvement obscures and distracts us from the real issues at stake during the 1940s.

The fact of Soviet involvement, or at least acquiescence, does little to help us understand the motivations of those carrying the rifles. An investigation of self-understandings should be central to understanding the ETR movement, and these factors are much more complicated than initially meets the eye. As this small case study of the Sibe cavalry unit has demonstrated, ethnic difference alone cannot account for inter-ethnic conflict. During the early years of Sheng Shicai's rule, probably few Sibe would have imagined going to war against the governor. In this period, Sheng was tolerant and supportive of a variety of new Sibe cultural institutions and organizations. Many members of the Sibe community even supported his elimination of the banner system in 1938. However, six years later and thirty-three years after the fall of the Qing, military service remained a central component of Sibe definitions of their community, and this point of pride was one that strongly influenced the decision to join the war against the Chinese Nationalists.

The complexity of Sibe self-understandings or, put differently, the struggle to make the transition from bannerman to Sibe, may account for the seemingly contradictory series of alliances that the Sibe made over the course of the early twentieth century. Moreover, the struggle within the Sibe community over the preservation of the banner system and the network of cultural and ethnic ideals it represented may have been more divisive and violent than the sources used for this paper make out. In oral interviews, Šumutong hinted that his electoral contest with Cangdešan reflected a much larger and more dangerous struggle that was occurring within Sibe society and would not reach its climax until the after the founding of New China in 1949. A cursory glance through the dossiers of the Ningxi (Cabcal) County Public Security Bureau archives indicated that Cangdešan and Eršan were both accused and convicted of being anti-revolutionaries during a mass meeting in 1951 . Both were subsequently shot. ${ }^{150}$

Yet at this time it remains impossible to write more concretely about this history because we know so little about the political and cultural institutions of Cabcal. How, for instance, had the Sibe banner system itself changed in absence of the larger Qing colonial military structure? The history of the cultural organizations and schools founded in Cabcal from 1911-1949 also remains to be studied. What was the content of the

149. Funggantai, "Guanyu Sanqu geming Xibo qibing lian de pianduan huiyi,” 106.

150. Šumutong, interview, August 15, 2007. The Cabcal County archives contain Cangdešan's personal confession to being a counterrevolutionary, written in Manchu script. 
educations being provided by the new Sibe schools? What was their view of China, and what place did they see for themselves in a Chinese state? At what point did Sibe begin to fear, as many do now, that the assimilating pressures of Chinese culture would eliminate their separate language and identity? The case of the Sibe participation in the ETR military demonstrates most clearly that, much like other non-Han groups who had lived at the perimeter of the Qing empire, loyalties to the new Chinese nation-state did not automatically transfer.

It is curious though, that the Sibe were the first ethnic group to receive "autonomous" privileges under the new Communist state. The Sibe-Solon village of Ice Gašan was established as the first "minority ethnicity village" in November of 1953. The next year, when Xinjiang was reorganized administratively as the Xinjiang Uyghur Autonomous Region, the Cabcal Sibe Autonomous County was established despite the fact that the majority of the residents were Uyghur or Kazak. Was this a legacy of the Sibe involvement in the Three Districts Revolution? Is this because the CCP was least worried about the Sibe trying to transform their areas into independent counties? Or was this, as Gardner Bovingdon suggests, the result of a realpolitik decision on the part of CCP strategists to break up the cohesiveness of the new Ili Kazak Autonomous Prefecture, the new administrative unit based on the former territories of the ETR? ${ }^{151}$ At the very least it reflected the fact that despite the various challenges faces by the Sibe communities over the first half of the twentieth century, the eight niru had retained their distinctiveness in both their own eyes and those of the state. Moreover, it suggests that the new communist regime believed that the maintenance and support of this unique community could be a useful strategic asset, as it had been to the Qing dynasty and subsequent warlord regimes.

\section{Bibliography}

Benson, Linda. The Ili Rebellion: The Moslem Challenge to Chinese Authority in Xinjiang, 1944-1949. Armonk, NY: M. E. Sharpe, 1989.

Bovingdon, Gardner. "Contested Histories." In Xinjiang: China's Muslim Borderland, ed. S. Frederick Starr, pp. 353-375. Armonk, NY: M.E. Sharpe, 2004. Autonomy in Xinjiang: Han Nationalist Imperatives and Uyghur Discontent. Policy Studies 11. Washington, DC: East-West Center, 2004.

Brophy, David. "Tending to Unite? The Origins of Uyghur Nationalism.” PhD Dissertation, Harvard University, 2011.

Cao Guofang 曹国芳. “Sulian yu sanqu geming qianxi Xinjiang bianjing diqu de shehui zhengzhi jushi” 苏联与三区革命前夕新疆边境地区的社会政治局势 (The Soviet Union and the social and political situation in the Xinjiang border region on the eve of the Three Districts Revolution). Beijing keji daxue xuebao (shehui kexue ban) 北京科技大学学报 (社会科学版) 2005.4: 123-27.

151. Bovingdon, Autonomy in Xinjiang, 13. 
Ding Lijun 丁立军. “Xinjiang Xibozu dui zuguo de weida gongxian” 新疆锡伯族对祖国的伟大贡 献 (The great contribution of Xinjiang's Sibe to the motherland). Xinjiang Xibozu yuyan xuehui xuehui tongxun 新疆锡伯族语言学会学会通讯 15 (2006): 11-13.

Donjina. Donjina-i sabuha donjiha ejebun (Donjina's memoirs of things seen and heard). Ürümchi: Xinjiang renmin chubanshe, 1987.

Feng'antai 丰安太 [Funggantai]. “Guanyu sanqu geming Xibo qibing lian de pianduan huiyi” 关于 三区革命锡伯骑兵连的片断回忆 (An incomplete recollection of the Sibe Cavalry Company during the Three Districts Revolution). Translated by Ying Lin 英林. Yili wenshi ziliao 伊犁文史 资料 6 (1990): 95-108.

Forbes, Andrew D. W. Warlords and Muslims in Chinese Central Asia: A Political History of Republican Sinkiang, 1911-1949. Cambridge: Cambridge University Press, 1986.

Gao, James Z. “The Call of the Oases: The 'Peaceful Liberation' of Xinjiang, 1949-53.” In Dilemmas of Victory: The Early Years of the People's Republic of China, edited by Jeremy Brown and Paul G. Pickowicz, pp. 184-204. Cambridge, MA: Harvard University Press, 2007.

Guo Jinan 郭基南. Saikan Gebu Amgade Ulabumbi (Convey a beautiful name to the future). Ürümchi: Xinjiang renmin chubanshe, 1993.

Harris, Rachel. Singing the Village: Music, Memory and Ritual Among the Sibe of Xinjiang. British Academy Postdoctoral Fellowship Monographs. Oxford: Oxford University Press, 2005.

He Ling 贺灵, Tong Keli佟克力, and Tong Yuquan 佟玉泉. Xibozu baikequanshu 锡伯族百科全书 (The encyclopedia of the Sibe). Ürümchi: Xinjiang renmin chubanshe, 1995.

Hong Tao 洪涛. “Lun Ahemaitijiang, Abasufu fandui Ailihan Tulie fenlie zuguo de douzheng” 论阿合 头提江、阿巴索夫反对艾力汗 - 吐烈分裂祖国的斗争 (On the effort by Ahemaitijiang and Abasuof to fight against Ailihan Turei’s Separatism). Xinjiang daxue xuebao (shehui kexue ban) 新疆 大学学报 (社会科学版) 2004.3: 72-77.

Ji Qing 吉庆. “Sanshisi wei yingxiong zhi ge” 三十四位英雄之歌 (The song of thethirty-four heroes). Yili wenshi ziliao 伊犁文史资料 19 (2003): 121-24.

Jin Binzhe. Sibe-English Dictionary. Unpublished manuscript, 2001.

Lattimore, Owen. The Pivot of Asia: Sinkiang and the Inner Asian Frontiers of China and Russia. New York: AMS Press, 1975.

Liu Zhixiao 刘志霄. Weiwu'erzu lishi维吾尔族历史 (The history of the Uyghurs). Beijing: Minzu chubanshe, 1985.

Mujingga 穆精阿, trans. Yili Xiboying zongguan Ka-er-mang-a fen cheng shu Yili jiangjun Wuliyasutai jiangjun Tacheng canzan dachen daizou zhi bingtie 伊利錫伯營總管喀爾莽阿分呈署伊利將軍 烏里雅蘇臺將軍塔城參贊大臣代奏之禀帖. Unpublished manuscript in collection of He Ling 贺灵, 1958.

Rudelson, Justin Jon. "Uighur Historiography and Uighur Ethnic Nationalism.” In Ethnicity, Minorities, and Cultural Encounters, edited by Ingvar Svanberg, pp. 63-82. Uppsala: Centre for Multiethnic Research, Uppsala University, 1991.

Sabir, Zordun. Ana Yurt (Motherland). 2d ed. Ürümchi: Šinjang yašlarosmurlar našriyati, 2000.

Schluessel, Eric T. "Thinking Beyond Harmony: The 'Nation' and Language in Uyghur Social Thought." In On the Fringes of the Harmonious Society, edited by Trine Brox and Ildikó Bellér-Hann, pp. 31845. Copenhagen: Nordic Institute for Asian Studies, 2014.

Sibe uksurai šolokon suduri (The concise history of the Sibe). Ürümchi: Sibe Uksurai Šolokon Suduri Banjibume Dzu, Xinjiang renmin chubanshe, 1993.

Šumutong 舒慕同. “Guanyu sanqu geming shiqi Sumuer xian de pianduan huiyi” 关于三区革命时 期苏木尔县的片断回忆 (An incomplete recollection of Sumul County during the Three Districts Revolution). Yili wenshi ziliao 伊犁文史资料 6 (1990): 43-56.

Tong Keli 佟克力. “Xiboying Xianghuangqi Tongjiashi jiazu yu Eluosi wenhua jiaoyu” 锡伯营镶黄旗 
佟佳氏家族与俄罗斯文化教育 (The Tong clan of the Bordered Yellow Sibe Banner and Russian education). Unpublished manuscript, 2007.

Tong Qichun 同奇春. “Sanqu geming shiqi Xibozu de jinjiu yundong” 三区革命时期锡伯族的 禁酒运动 (The prohibition movement among the Sibe during the Three Districts Revolution). Chabucha'er Xibozu zizhi xian wenshi ziliao察布查尔锡伯族自治县文史资料 I (1996): 85-90.

Ujalan Liyanšeng 吴连胜. Sibe Moringga Liyan Coohai Ejebun (Memoir of the Sibe Cavalry Company). Ürümchi: Xinjiang renmin chubanshe, 1987.

Wang, David D. Under the Soviet Shadow: The Yining Incident: Ethnic Conflicts and International Rivalry in Xinjiang, 1944-1949. Hong Kong: The Chinese University Press, 1999.

Wu Haomin 吴浩民. “Šive atliq iskadroni heqqide eslime” (True memoir of the Sibe Cavalry Company). Sinjang tarikh matiriyalliri 35 (1993): 49-91.

Wu Liansheng 吴连胜 [Ujalan Liyanšeng] and Tong Keli 佟克力. “Xibo qibing lian jishi” 锡伯骑兵 连纪实 (Record of the Sibe Cavalry Company). Unpublished manuscript, 2007.

Xibozu jianshi 锡伯族简史 (Concise history of the Sibe). Beijing: Xibozu jianshi bianxie zu, Minzu chubanshe, 1986.

Xinjiang Xibozu renwulu 新疆锡伯族人物录 (Biographical Dictionary of the Sibe people). Ürümchi: Xinjiang Weiwuer zizhiqu neibu ziliao, wenshi ziliao weiyuanhui hebian, 2001.

Xu Yuqi 徐玉圻. Xinjiang sanqu geming shi 新疆三区革命史 (A history of the Three Districts Revolution). Beijing: Minzu chubanshe, 1998.

Xue Xiantian 薛衔天. “Shilun minzu yinsu dui Sulian tiaoting Sanqu geming de yingxiang” 试论民 族因素对苏联调停三区革命的影响 (Discussion of the influence of ethnic factors in the USSR's intervention in the Three Districts Revolution). Zhonggong dangshi yanjiu 中共党史研究, 2003.1: 68-74.

Yili shibian ji 伊利事變記 (Record of the Ili incident). In Xibozu minjian sancun Qingdai Manwen gudian wenxian 锡伯族民间散存清代满文古典文献, edited by Tong Yuquan and Tong Keli 佟 克力. Ürümchi: Xinjiang renmin chubanshe, 2008. 